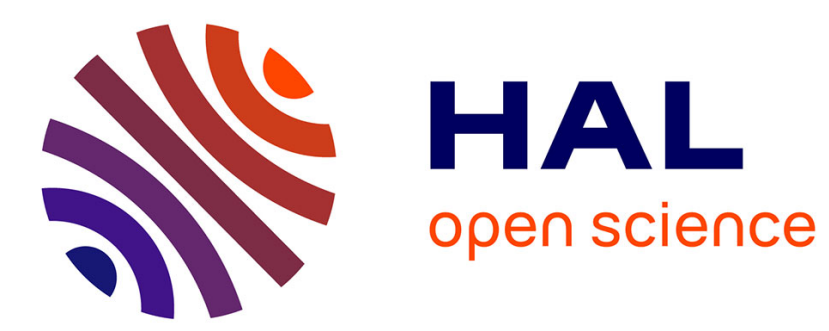

\title{
Politics of mass rapes in ethnic conflict: A morphodynamics of raw madness and cooked evil
} Albert Doja

\section{To cite this version:}

Albert Doja. Politics of mass rapes in ethnic conflict: A morphodynamics of raw madness and cooked evil. Crime, Law and Social Change, 2019, 71 (5), pp.541-580. 10.1007/s10611-018-9800-0 . halshs01319734

\section{HAL Id: halshs-01319734 \\ https://shs.hal.science/halshs-01319734}

Submitted on 16 Sep 2019

HAL is a multi-disciplinary open access archive for the deposit and dissemination of scientific research documents, whether they are published or not. The documents may come from teaching and research institutions in France or abroad, or from public or private research centers.
L'archive ouverte pluridisciplinaire HAL, est destinée au dépôt et à la diffusion de documents scientifiques de niveau recherche, publiés ou non, émanant des établissements d'enseignement et de recherche français ou étrangers, des laboratoires publics ou privés. 


\section{Politics of mass rapes in ethnic conflict: a morphodynamics of raw madness and cooked evil}

\section{Albert Doja}

Crime, Law and Social Change An Interdisciplinary Journal

ISSN 0925-4994

Volume 71

Number 5

Crime Law Soc Change (2019) 71:541-580

DOI 10.1007/s10611-018-9800-0

\section{Crime, Law and Social Change}

Editors-in-Chief

Mary Dodge and Wim Huisman

\section{Q Springer}

\section{琞 Springer}




\title{
Politics of mass rapes in ethnic conflict: a morphodynamics of raw madness and cooked evil
}

\author{
Albert Doja ${ }^{1}$ \\ Published online: 13 November 2018 \\ (C) Springer Nature B.V. 2018
}

\begin{abstract}
To explain war rapes in former Yugoslavia, the work of cultural ideology is never complete, but an unstable relation between cultural activism and cultural norms and practices provides the point of departure to move beyond the stereotyped accounts of mass rapes and develop a neo-structural model of canonical formalization based on discourse analysis and transformational morphodynamics. Methodologically, the new model takes lead from the abstract mathematical operations and canonical transformations suggested by Lévi-Strauss for the structural study of myth. The assumption is that mass rapes are fueled by a specific cultural activism that activates a cultural ideology that makes mass rapes effective in a military strategy of ethnic cleansing.
\end{abstract}

\section{Introduction}

Research on sexual violence has been important to identify the historical, strategic, organizational, political, ideological, and cultural factors that drive rape and other forms of sexual abuse during wartime. Moving beyond feminist and other commitments in explaining war rapes during the ethnic conflicts in former Yugoslavia and elsewhere, this article explores the reified conceptualization of so-called Balkan social structures, norms, and values, including the Albanian case of social morphology, as a typical imagination of Southeast European cultures and societies. The aim is not, however, to review or discuss the homogenized conceptualization of war rapes by women's groups, media and scholarship that combined feminism and the Balkanist variant of Orientalism, which might have had some validity for the earliest phases of the uneven propaganda battles between Serbs, Croats, Bosnians and their media and intellectual extensions at home and abroad. A number of existing studies now criticize and go beyond the poor frameworks that essentialize local cultural practices and international public representations of Balkan backwardness for explaining ethnicized mass rapes in

Albert Doja

albert.doja@univ-lille.fr; http://orcid.org/0000-0001-5378-8362

1 University of Lille, Clersé CNRS UMR 8019, Cité Scientifique SH2-205, 59655 Lille, France 
former Yugoslavia. They already show that wartime sexual violence is not a cultural given but a strategically used weapon. They also critically address the connection between ethnicity, kinship and gender through direct engagement with local discourses and the experiences of mass rape survivors. Yet, the description of cultural norms and practices, however resourceful, may hark back and end up essentializing them anew.

In this area, it is important to distinguish between behavioral norms and rules of what most people actually do and say in practice, and which may be explored ethnographically, and ideal norms and rules for what people ought to do and how they ought to behave. The latter cannot be observed ethnographically. It is only inferred as a kind of what is called elsewhere "cultural activism", or a kind of a "cultural Viagra" for social survival, which promotes the active support of particular cultural values and practices to uphold the existing state of social affairs by means of vigorous ideas of cultural coherence [1]. ${ }^{1}$ In addition, the work of cultural ideology is never complete, and there is an unstable relation between cultural activism and actual cultural norms and practices, which depends on particular social and political conditions.

This instability provides the point of departure to move beyond the traditional accounts of mass rapes in former Yugoslavia and develop a neo-structural model of canonical formalization based on discourse analysis and transformational morphodynamics. Methodologically, the new model takes lead from the abstract mathematical operations and the evolution rules of canonical transformations suggested by Lévi-Strauss for the structural study of myth, which make it necessary to isolate an analytical device as a boundary condition for mathematical validation. In the following section, I provide the historical and epistemological context of structural methodology. The next section takes issue with a number of intellectual interpretations of wartime rape strategy across several disciplines. The main argument for a morphodynamic approach to mass rapes is developed in the third section, followed by another section where the concept of cultural activism is argued as a boundary condition that may reasonably account for the political effectiveness of mass rapes as a military strategy of ethnic cleansing.

\section{Structural methodology}

Today anthropology is concerned with questions of feminism, reflexivity, identity politics, ethnic conflicts, civil wars, human rights, cultural activism, fundamentalism, and many other related themes. An attempt to restore Lévi-Strauss to a central position can hardly meet immediately with many of the current social and political issues. Yet it is possible to show that structural anthropology may innovatively account for much more than the dynamics of social systems and the praxis of competitive and strategic behaviors, including the effectiveness of mass rapes as a military strategy and instrument of ethnic cleansing. Indeed, Lévi-Strauss anticipated and called for the advent of what must be the future of a theoretical anthropology to come [3-7]. Contrary to the received ideas of his critics, little of recent topical, ethical, methodological or epistemological interest escaped Lévi-Strauss's notice, understanding and engagement. In his

\footnotetext{
${ }^{1}$ Cultural activism corresponds to the traditionalist and survivalist principles of the World Values Survey cultural map [2].
} 
writings, we can find the seeds of a new epistemology and a new ethics, involving a set of new assumptions and procedures for the acquisition of knowledge, a new approach to methodology and a new global awareness.

However, particularly in the English-speaking world, the true value of Lévi-Strauss's works has been obscured by a number of misunderstandings, no doubt been exacerbated by problems of cultural rather than linguistic translation, as well as by the vagaries of intellectual fashion. Just but to equate Lévi-Strauss with structuralism, for instance, is to distort our understanding of his legacy and his continuing relevance in anthropology and social theory. Indeed, while revisiting the old debate between Derrida and Lévi-Strauss on the place of writing $[4,8,9]$, we came to the conclusion as many others (e.g. [10]) that we must legitimately ask to what extent, in the popular imagination at least, a version of structuralism invented retrospectively by "poststructuralists" has become substituted for the real thing. Not only Lévi-Strauss's original approach to history, but above all his actual theoretical and epistemological contribution to general knowledge and the humanism of structural anthropology as a human science are seemingly neglected and rarely appreciated, if not deliberately misconstrued, despite the fact that they are essential aspects of Lévi-Strauss's theory.

Some of these aspects could lay strong claim to having mapped, within anthropology, the philosophical parameters of an increasing preoccupation with issues of contextualization and reflexivity in the face of the declining coherence of metanarrative and grand theory, as well as with issues of political concern and engagement in the post-colonial era. To the extent of the impact of the new form of humanism initiated by structural anthropology [11], we may be correct in asserting that LéviStrauss used structural arguments coherently and correctly to analyse the cultural order. At the same time, he recognized the transient character of this order by means of entropy and irreversibility, and not surprisingly, deconstruction or rather "dissolution", to use his own term, and self-reflexivity. Arguably, some of these and other aspects of Lévi-Strauss's theory may be advanced as a workable methodology helping us to build innovative anthropological approaches to agency and politics in history, culture and society.

Actually, a more closely argued and clearly defined theoretical framework could be designed by means of a careful combination of Lévi-Straussian structural analysis, cognitive commitments, borderland epistemology and the politics of practice and agency. Though this must claim further examination at another time, we may argue that such attempt could provide another instance in which our theoretical understanding of the world can be made to progress, in the context of a general revival of the kind of vigorous theoretical debate that tended to disappear from the field after the postmodern-poststructuralist turns in the 1980s. A thorough critique of the postmodernist rhetoric of post-structuralism [4, 8, 9], provided elsewhere in a broader context of the reassessment of structural legacy in anthropology $[3,5,11]$, may be considered as a new step toward the innovative movement and reflexive project of neo-structural constructivism $[6,7,12]$. In particular, the theoretical project inspired by the canonical formalization in the structural analysis of myth can show that structural anthropology is intimately concerned with processes of social conflict, change, praxis and agency [13]. Arguably, such neglected but potentially vigorous development in current social and anthropological theory may not only present new empirical material and substantive findings, but also 
generate a novel conceptual and theoretical synthesis to open up innovative research avenues.

Lévi-Strauss described the generative engine of myths on the basis of the set of their own transformations by means of a series of terms that are qualified with different functions. The terms can be characters, things or concepts and categories that are able to take certain roles. The functions are the different roles carried by these terms. In mythical networks, the basic transformations that Lévi-Strauss distinguished between a number of characters or terms of myths and their large number of possible roles or functions can be of the kind of homology, inversion, opposition, or symmetry. He also highlighted how these terms and these functions are controlled in mythical thinking by means of a special relationship that he formulated in a canonical way, which demonstrates how the transformations of the myths can be captured. Lévi-Strauss's concept of canonical formulation that articulates the transformational dynamics of mythical networks transcends a simple analogical relation to a quadratic equation, $\mathrm{Fx}(\mathrm{a}): \mathrm{Fy}(\mathrm{b}): \mathrm{Fx}(\mathrm{b}): \mathrm{Fa}^{-1}(\mathrm{y})$, which articulates a dynamic homology between meaningful elements and their propositional functions. This formulation made it possible for Lévi-Strauss to detect a sort of genuine logical machine generative of open-ended meaning within specified mythical networks.

After the method for the structural study of myth was introduced [14], the generative virtues of the so-called "double twist" of canonical transformation have remained not understood for a long time. Lévi-Strauss almost never mentioned explicitly his formulation of transformational dynamics, even though this was implicit in the massive work of his Mythologiques series published between 1964 and 1971 [15-18]. The morphodynamic principles of canonical transformations were explicitly operationalized only in his more recent inquiries published between 1985 and 1991 [19, 20]. One may not know that, but this does not mean, as an anonymous reviewer of a previous version of this article submitted to a major anthropological journal claimed, that Lévi-Strauss did not understand his own theories and that only advanced mathematicians are up to that task. Instead, we might wonder where that might bring anthropologists, were we to understand that we have to wait, starting from 1972 [21, 22], for the knowledge progress in qualitative mathematics become sufficiently advanced for us to understand Lévi-Strauss's theories. Especially, after they were made comprehensible as an anticipated formalization of catastrophe models in new mathematics and morphodynamics [23-27]. It may be then more conceivable we could use them in approaching the politics of wartime rapes in former Yugoslavia and elsewhere.

In a broad sense, which is highly relevant to the analysis of wartime rapes, while the key categories that Lévi-Strauss developed are embodied in the anthropological objects he studied (myths and mythical networks), they have the potential to be usefully and critically applied to other domains if radically tweaked. Many studies show that the structural analysis initiated by Lévi-Strauss may innovatively account for the ways in which social relations are ever more mediated by and implicated in broader political processes [28-30]. In particular, the requirement of an operating condition that in the study of myth is expressed as a boundary condition in mathematical sense may be of particular interest for the study of ideology and agency. 
The heuristic relevance of Lévi-Strauss's notion of "canonical formulation" is shown explicitly in the comparative analysis of transformations resulting from intercultural dynamics and social change $[13,31] .^{2}$ In this article, the main assumption is that mass rapes are fueled by a specific cultural activism that activates the cultural ideology of family honor and blood purity. The neo-structural model is expected to uncover discursive activation of the instrumental politics of cultural activism as a logical necessity that promotes a new hidden agency, which could explain the effectiveness of mass rapes as a military strategy of ethnic cleansing in former Yugoslavia and provide a more analytical framework to rethink comparatively interethnic mass rapes in other contexts.

Traditional accounts of mass rapes have performed an important role by naming the suffering, recognizing the multiple victims, and condemning the actions of the perpetrators as an international crime. Feminist political and legal commitments in explaining war rapes during the ethnic conflicts in former Yugoslavia can be read as doing just this, and doing so with demonstrable sympathy for the victims of sexual violence, despite their unintended reified conceptualizations. Against the backdrop of suffering, my neostructural analysis of instrumental politics could appear as a curious intellectual exercise, detached from the horror of extreme violence. However, the terms by which the mobilization of cultural activism produce categories of violence and categories of victims may have implications for how post-conflict and post-violence social repair can take place.

\section{War rapes in former Yugoslavia}

It should be no surprise that the rape of women is an old phenomenon, always been part of warfare and genocide, and flourishes irrespective of nationality or geographic location. Given the massive occurrence of the phenomenon and the ineffectiveness of international arrangements, the question arises as to which purpose and which function rapes do have in wars. Cases of systematic use of rape and sexual violence are multifarious and the explanations offered are manifold, as the issue received muchneeded attention from scholars across multiple disciplines in recent years. Yet, most scholars are consumed with the patterns of rape that vary widely in scope, scale, purpose, and form between and within conflicts $[49,50]$. Some of them even employ much ingenuity to test statistically a host of explanations for the variation by using the best proxies available [51,52]. Among dominant patterns of causal attributions and representations, several layers of causation may be noted. It is not just that sexuality and violence may be manifest together in troubled times, but that the mass rape and sexual assault appear standardized in certain ways.

Rape may be analyzed by its effects on male group dynamics, military rankings, state and ethnic formations, forms of political recruitment, family reorganization, gender relations, economic and rural/urban differentiation, and forms of political recruitment and religious purity/pollution. Conflict-related rape and gender-based

\footnotetext{
${ }^{2}$ Structural methodology is implicit in previous works on social morphology [32, 33], processes of identity construction and cultural socialization [34,35], women's agency [36], the myth of many children within the so-called Albanian patriarchal extended family [1], the religious movements during much of Southeast European history and politics [37-44], the narrative legacies and international representations of Balkan wars and their implications in regional and international politics [45-47], or the transformations of European identity [48].
} 
violence are a critical issue of human security and a threat to post-conflict reconstitution and prosperity. Still these effects may clarify why mass rape systematically continues, but they may not explain why rape occurs in ethnic conflicts, they do not show why mass rape becomes an effective weapon of the military strategy of ethnic cleansing, and we know little about what can be done to prevent them. This is because many explanations fail to take into account the social construction of group interests, security priorities, and perceptions of right and wrong through social interaction and strategic framing of particular narratives. Some of these explanations neglect to theorize mass rapes both as salient markers and as securitization issues of gender, ethnicity, and state categories at the same time. In particular, they virtually dismiss the structural dimensions of instrumental rape as illustrated during the sinisterly known ethnic conflicts in former Yugoslavia, which might bring forth rather more productively a concern both with public culture and with political approach.

When war broke out in former Yugoslavia in the early 1990s, rape became an important topic that deserved close scholarly attention, especially with reference to those aspects of gender and sexuality that are related to ethnicity. While men from all ethnic groups committed rape, reports of sexual violence during the Bosnian War (1992-1995) and the Kosovo War (1998-1999) perpetrated by the Serbian military and paramilitary forces have been described as "especially alarming" ([53]:9). Many of the patterns of violence directed at civilians appeared to confirm feminist analyses of the vulnerability of women in ethnic-nationalist conflicts. Gender-targeted violence once again brought rape in wartime to the attention of the world. Since then, many consider that rape is more common in certain types of conflict, namely ethnic conflicts, genocides, and secessionist movements, where it correlates with other forms of violence.

An important factor contributing to public awareness of the magnitude of rape and sexual atrocities during the ethnic conflicts in former Yugoslavia has been the increased activism of journalists, aid workers and feminist scholars in connection with the international mobilization on behalf of the Bosnian victims of sexual violence. ${ }^{3} \mathrm{~A}$ leading feminist analysis of these rapes was an edited collection [54], which included a range of feminist voices, along with numerous other journal articles, symposia and books [55-58]. They came to focus on rape as a weapon of war, an instrument of genocide, an engine of war, a war tactic, and so on. These expressions reflect a conception of sexual violence as having a systematic, pervasive, deliberate, or officially orchestrated function in furthering militaristic, masculinist and/or nationalist goals such as the destruction of a community [57, 59-63]. All emphasize that rapes "are not random acts, but appear to be carried out as deliberate policy" ([64]:658; [65]). In such contexts, rape is a political event, located within militaristic or nationalist agendas and requiring substantive analysis and action.

In most militarized conflicts, rape serves as a strategy to intimidate, degrade, humiliate, punish, and torture, aimed as a retribution to undermine and emasculate the enemy. In some cases, rape is a prelude to death. In other cases, rape may be a tactic

\footnotetext{
${ }^{3}$ Major newspapers and media from many countries and a high number of organizations have collected data and written up reports, commentaries and accounts that have given rise to an enormous though widely divergent literature on wartime rape, published in print or posted on their websites, both in Western countries and in former Yugoslavia.
} 
of secessionist groups intended to signify the end of inter-group relationships [66], or it may be part of a larger campaign of ethnic cleansing or annihilation, aimed to deactivate communities and force civilians to abandon territory, in order to assert ethnic and political dominance. In most cases, rape often involves compulsory performances of the perpetrator as well as the victim who must enact public rituals of degradation before significant others.

In the emergence of the global campaign on violence against women, the issue of rape in the Yugoslavian wars, framed as an attack and a method of ethnic cleansing against the individual and the collectivity, emerged as a condensation symbol, capable of evoking deep emotions and provoking suitable responses ([67]:628). Feminist arguments for the recognition of rape as a weapon of war ultimately gained legal traction and ultimately became crucial in the establishment of the International Criminal Tribunal for the former Yugoslavia [68], which was prompted to deal openly with these abuses. The ad-hoc International Tribunal work owes much to the activism and effort of feminists who had a substantial impact on its determinations that rape is a war crime and more specifically can constitute a crime against humanity $[69,70]$, leading to a greater political visibility of the practice of systematic rape as an instrument of ethnic cleansing and genocide. 4

However, the attempt to protect women's human rights and to pressure international institutions to prosecute rape as a war crime has been manipulated primarily by local governments, politicians and nationalists, but also by local and international journalists and the media. One of the most disturbing aspects of war rape in former Yugoslavia is the special explosion of extensive media coverage surrounding the sensationalized reporting of systematic mass rape, sexual violence and other war atrocities, aimed to amplify nationalist fervor rather than to help the traumatized women. For multiple reasons, political and politicking, the excessive role of mass media and modern technology in the coverage process of ethnic war in former Yugoslavia, including the vagaries of the last episode in Kosovo, was for long widespread in almost all Western countries. Indeed, many worried about the fact that some of the media coverage appeared to have taken on a life of its own, creating a kind of hysteria far from the experience of the individual victims.

Western media is very often accused of adopting a voyeuristic attitude towards the rapes [55]. The mobilization of the international community might have subjected raped women to a new form of humiliation by the media, to use an infamous phrase, by "turning rape into pornography" [60]. Not only rumors about the existence of videotapes of rapes circulating on the international pornography market but also American journalist's jokes or apocryphal stories confirmed the horror of the voyeuristic gaze of the West. Activists report that Western journalists barged in refugee camps offering some women substantial money to tell their story to the international press, or major news organizations sent faxes to interview women about the rape camps in former Yugoslavia [71]. One fax received by the Zagreb Centre for Women War

\footnotetext{
${ }^{4}$ In both Rwanda and former Yugoslavia, the International Tribunal was the first institution to convict for using rape as a weapon of war and to recognize that systematic rape and sexual enslavement in time of war was a crime against humanity and an instrument of genocide. See UN International Residual Mechanism for Criminal Tribunals, ICTR-96-4-T (1998), ICTR-96-4-A (2001), http://unictr.unmict.org/en/cases/ictr-96-4; UN International Criminal Tribunal for the former Yugoslavia, IT-96-23-T \& IT-96-23/1-T (2001), IT-9623-A \& IT-96-23/1-A (2002), http://www.icty.org/en/case/kunarac/4.
} 
Victims entered into legend: "Raped Bosnian women, possibly pregnant and speaking English, were in great demand" ([72]:79).

More importantly, as shown elsewhere [73], some scholars lend themselves to this voyeurism with a quite intellectualistic and Eurocentric cast. In their approach, they prefer the impulsive aspect and the aesthetic representation of rapes throughout the war in Bosnia, since in war or outside war the most significant fact for them is not "the sociological reality of war as a field of cruelties" but "the cruelty that becomes the highlight of aesthetic production" ([74]:190-191). References to the aesthetic in the context of atrocity are always uncomfortable and raise unavoidable questions about the ethics and the power dynamics of representation, the potential for sensationalism, ideological appropriation and obfuscation, and the risks of re-traumatizing and reifying victims inherent in acts of representing trauma.

Not only the televised report of rapes on the evening news was used in nationalist media as a highly effective tool in the propaganda war, but there are indications that some women in Bosnia and Kosovo have also seen the international focus on rape as depriving women of personality and agency ([66]:35). Women's groups activists have very often discussed how documentation of the use of sexual violence in the wars in former Yugoslavia was employed as propaganda especially in the Western media. The issue of sexual abuses against women was often manipulated for political advantage in order to spread war propaganda, to aggravate ethnic-national hatred, to manipulate Western populations according to the needs of daily politics, and to raise readership and viewing rates.

It is hugely difficult to make sense of the sexual exploitation and victimization of women in times of war, not simply because of the difficulties of theorizing rape in general, which may rely on a professionally conditioned deformity that lends itself to media mechanism and intellectualism. A growing body of feminist scholarship has examined post-conflict justice mechanisms such as war crimes tribunals, truth/ reconciliation commissions, peace agreements and international legal instruments as spaces within which gender norms and identities are defined and reiterated [75-78]. The post-conflict period is often heralded as a richly transformative time in which social and political relations can be reconstituted, but this literature has also mapped how gender identity and relations are often reiterated in conservative ways, particularly through the assessment of gender and sexualized harm [67, 79, 80].

Feminist analyses suggest that when women testify about their own suffering, their evidence tends to be constrained by the trial or commission process, which limits what women can speak of, or re-interprets their evidence as tales of sexual violence and gender inequality [81-84]. The result is a series of "blind spots" in transitional justice both about women's experience of conflict and about the structural effects of inequality that hinge on large-scale violence. In particular, feminist legal scholars have critiqued the ways in which transitional justice institutions persistently elide victim with women and women with sexual violence as well as the intricate relationship between how harms are identified and the constitution of particular subject positions in post-conflict justice mechanisms that construct women as a particular type of victim.

International courts and transitional justice institutions have recognized that gender and gender inequality produce certain kinds of gendered violence and victims during periods of extreme conflict [85], which become profoundly destructive and a "fate worse than death" for women of traditional societies. Naming and recognizing 
gendered forms of harm can have an important performative dimension that signals international condemnation of violence against women, which has been an important feminist political and legal objective, seen as essential to a transitional reconstitution of social and political order. However, over the course of the 1990s, the consensus that emerged among the feminists as a joint representation of their worldview, argument repertoire, and reform agenda was not, as one might expect, a liberal feminist view that could split the difference between conservative and leftist feminist ideologies. Instead, a new feminist organizational style and capacity evolved rapidly into a "governance feminism" [86], a term used to capture the complex ways in which the nongovernmental activism adopted by feminists aiming to advance specific social interests infiltrate the State with non-state prescriptions for political engagement with law and new governance formations. The manifest consensus and the coalitional style adopted by governance feminists yielded an updated radical feminism, strongly committed to a dichotomist rule choices in the understanding of male domination and female subordination.

In a dichotomist feminist approach, which is tagged mistakenly by critics with a gratuitous and awkward qualification of "structuralist feminism", thinkers and actors hypothesize that a male/female distinction matters when in some domain of human affairs male is superior to female so as they could direct their efforts to carrying a brief on behalf of women [87]. More specifically, the new radical feminists think that women are a distinct human group suffering distinct harms and requiring distinct advocacy. Their ambition is to wield the sovereign power of the international legal order to produce absolute results, which is not to warn and deter but to end impunity, by putting a supreme emphasis on criminalization, prosecution, and punishment. Over the 1990s, these feminists discovered ways of implementing their dichotomist view that rape was not merely a tool of belligerent forces but part of a global war against women. As international legal reforms took shape, a new feminist idea was clarified, in which international law relating to armed conflict could be about women, not as a particular group of humanity but a universe of their own [78]. Such feminist universalism made it possible to look at the eruption of ethnic-nationalist conflict in former Yugoslavia as a war against women, which involved a chilling indifference to any acknowledgement that men suffered and died in it, ultimately reproducing in reverse the blind-spotted moral vision that it contests.

Feminist international security scholars have also written extensively on the ideological importance of a valorized misogynistic masculinity. They emphasize the extent to which the maintenance of group cohesion and effectiveness involves instrumental mechanisms of misogynistic training and bonding practices that are rooted in the larger discursive context of armed organizations as sites of masculinization through violence and gender-based violence $[88,89]$. Gang rape is often used as a socialization mechanism or a "rite of initiation" to bond forcibly recruited fighters and improve the morale of perpetrators. Serbian factions in the Yugoslavian wars also employed rape, which they identified as a "brotherhood of guilt" ([90]:112), to ensure that fighters could not leave their units for fear of having to reconcile their actions. Security scholars argue that in armed groups organizational factors take precedence over individual dynamics in driving violence against civilians [52]. In this argument, organizational pressures operate through a variety of mechanisms, including individual conformity to group norms and propensity to obey commands, because of the hierarchical structure and the social 
identity of armed groups, where members are often socialized into hyper-masculinist and misogynist group norms and preferences that promote collective sexual violence.

Similar attempts to consider mass rape outside of an immediate outrage or ascription of chaos and pathology threatens to become independent of compelling human concerns. There is perhaps a welcome relief in referring men's sexual violence to something other than their choices, especially when we relegate it to the workings of a masculine ideology, a psycho-physiological contingency, a by-product of sex-driven psychobiologism [91, 92], or an evolutionary adaptation and a natural history of rape [93, 94]. These approaches may claim some expedient attraction in clarifying why ordinary men can turn into rapists, but they are highly dubious and largely discredited, even though they may happen to be confirmed by asking both the perpetrators and the victims [95]. Whether there is an irrepressible urge or not, and what consequences it has, seems more likely to depend on the social conditions and on the construction of sexuality prevailing in a particular time and place, which may have in turn a considerable impact on the psyche and the emotional balance of the individual.

Not surprisingly, feminist scholars prepared the ground for an ahistorical approach [96]. From the start, they characterized rape as "a conscious process of intimidation by which all men keep all women in a state of fear" [97], arguing that the "terror warfare" of collective sexual violence [98] is only the frankest expression of men's power over women, as an emblem of the politics of gender aimed at the depersonalization of women. This standard dichotomist view, which is identified with much American feminist scholarship, is seen as a sufficient reason for the existence of the phenomenon and the development of rape ideologies that valorize misogynistic masculinity.

Prominent western feminists have extended their theorization of rape to wartime and genocidal rape, but they virtually continue to locate rape in male/female relations [99]. They may even come to the conclusion that rape is not a sexual but an aggressive act or describe rape as a "pseudo-sexual" or "anti-sexual" act that has nothing to do with sexuality but with the exertion of sexual violence directed against women. In line with older sex-drive theory approaches, rapes are considered a result of male sexual frustration in pre-industrial societies with strongly regulated sexuality. In this context, male sexuality is again established as an ahistorical constant, understood to follow the "hydraulic reductionist" theory of a steam boiler or pressure cooker [65]. According to this transgressive argument, also advocated by some psychobiological anthropologists, the expression and realization of uncontrollable male sexual propensities are usually checked by social sanctions but unleashed or promoted through the opportunities of war. Military rape would be "the unchaining of a generally disallowed biological imperative of absolute desire and destruction following an increase in individual power over others" ([100]:11). For radical feminists, men engaged in warfare, even if fighting on opposing sides, share an understanding of rape, prostitution, pornography and sexual killing as an excess of passion in peace or the spoils of victory in war.

In the last analysis, they refuse to consider that rape has a political concern not only when it is a crime of men against women, but also when it is linked to genocide as a crime against the group to which a woman is assumed to belong. Ironically, some feminists tend to subvert the political use of rape as an instrument of ethnic cleansing and genocide, simply because they assume this kind of argument would make women as individuals cease to exist and would "destroy the transnational solidarity of women who are less inclined than men to identify with the Nation" of their ethnic group 
([72]:80). Similarly, other human rights scholars also find problematic the language of ethnic cleansing and genocide in former Yugoslavia and try to play down the instrumental politics of mass rapes, simply because they believe this assumption would dictate in the first place a devastating effect on the human rights of children born of rape $[101,102]$.

These unnecessarily patronizing claims cannot explain mass rape in specific wartime contexts, such as the Bosnian war and the Kosovo war in former Yugoslavia or anywhere else. They tend to forget arguments that are more inclusive, such as those considering that gender relations and human rights crosscut other social and political relations and that gender identities are constitutive elements of other identities. In particular, they ignore anthropological feminist analyses of how rape was a weapon of genocide against women both as individuals and as members of specific ethnic groups [103, 104]. More generally, these interpretations overlook a wealth of both current anthropological scholarship and feminist normative criticism that historicize shifting gender dynamics and their relationship to political violence. If women on all sides suffered as rape victims, this does not need overlooking that rape was deployed and experienced differently as a weapon of war and instrument of genocide depending on local histories, ethnicities, interpersonal dynamics, and cultural norms.

The ideological importance of radical feminist and other ahistorical approaches is to assume an essential and everlasting misogynistic character of conflict-related rape, which inadvertently reifies the organizational factors and the politics of gender in armed groups. Such approaches rest on an essentialist view of masculinity as fundamentally aggressive and of femininity as fundamentally sensitive. They presume all men are inherently absolute aggressors limited only by social norms and all women are perfect victims to be protected by legal instruments. Yet, the Tribunal record is also claimed to constrain the types of victims and forms of harm that constitute the victim as naturally gendered [105]. Ultimately, the focus on sexual violence ends up defining women exclusively by the violations to their bodies, thus perpetuating their domination. The complexity of violence is also stripped away by a "narrower gendered focus on gross violations of human rights" when archetypal representations of the sexually abused "woman victim" stand in as a conceptual shorthand for the complexity of largescale violence and atrocity ([106]:74).

A reframing in gender terms flattens the complexity of women and men's experiences of violence and renders some victim subjects visible at the expense of others. In these frames, men are agents, while women are victims of sexual violence and innocent in matters of war and violence. Men may experience human rights abuse but women experience sexual abuse, which further impacts on the ways in which essential categories of women are positioned as always raped or inherently rapable and rape is depicted as almost a natural or inevitable gendered consequence of genocidal conflicts between polarized sides seen as essentially ethnic or nationalist. In the context of ethnic conflicts in former Yugoslavia, the representational power of the iconic woman victim integrated "specific lived experiences, of specific women and men within specific political and cultural contexts, with supposedly universal meanings" ([107]:13). In particular, a number of scholars made assertions about the presumed conservative, patriarchal and incidentally Islamic nature of Bosnian community, concluding that Bosnian women raped during the wars would experience heightened social stigma. This characterization, which mistakenly elided Bosnia in the former Yugoslavia with 
Muslim societies in the Middle East, was uncritically taken up and reproduced in public opinions in the 1990s.

Remarkably, even in the Krstic trial process at the International Tribunal, Bosnian women's lives in a traditional patriarchal society and their identity as Muslim rather than Bosnian become the dominant lens through which their experiences as victims of genocide were understood. ${ }^{5}$ The variable meanings and complexities of patriarchy as lived and understood both in Bosnian society [108] and in witness testimonies [106] are stripped away, and patriarchy is asserted as an universal Bosnian experience without nuance or context. In this way, the International Tribunal emerges as another integral part of a system of knowledge production that filters evidence and establishes official versions, not just about the past or about the social, political, and economic relations that structure violence and its effects ([106]:75), but also about the reified conceptualization of traditionalist gender inequalities, ethnic divisions, and culturalist oddities like patriarchalism.

In addition, the kind of pop-cultural feminism as reflected in public media narratives and representations had another Balkan variant, bringing a distorted image of Southeast European peoples as barbaric "tribal haters" outside the realm of reason and civilization. The implication was that violence and genocide are part of the local culture and therefore inevitable in the Balkans. Many commentators followed suit in an attempt to explain mass rape in terms of a supposed Balkan culture that encouraged a cult of manly heroism and violence $[54,55]$, a central theme of which became the exploration of the exotic forms of masculinist violence used in former Yugoslavia. Hence, the derisive comment prejudiced by feminist commitments that "Balkan men have proved eager to fight and die for their particular subdivision of Slavic ethnicity, which they further define by religious differences... But Balkan women, whatever their ethnic and religious background, and in whatever fighting zone they happen to find themselves, have been thrust against their will into another identity: They are victims of rape in war" ([109]:180).

Coupled with nationalist perspectives, the construction of a somehow uniquely Balkan image of Southeast European peoples also implied the reification of homogenous national groups into entities with radically different identities [110]. In particular, Serbian identity was set apart from the civilized world, seen as advocating vengeance and derived from "the blood-cloudy mists of extremist nationalist legends" of which the most important element is "the Chetnik cult of the knife" ([55]:80). The representation of rape as something to be expected during wartime will rely on the construction of a so-called Balkan tradition coming close to a construction of eternal ethnic hatred and brutality, since the Balkans have always had a repetitive history of violence. Historical continuity firmly in place, the discovery of mass rape in Bosnia or in Kosovo will not seriously shake the foundation of this discourse.

Another way of approaching the dimensions of mass rape and sexual violence during the sinisterly notorious ethnic conflicts in former Yugoslavia has been to explain them specifically against the cultural background, among other things by using local concepts such as blood ideology and family honor. They are supposedly supported by the existence of a tribal society, complex joint family structures known as zadruga in

\footnotetext{
${ }^{5}$ UN International Criminal Tribunal for the Former Yugoslavia, IT-98-33-T (2001), IT-98-33-A (2004), http://www.icty.org/case/krstic/4.
} 
South Slavic areas, customary laws known as Kanun in North Albanian area, patriarchal practices, and other savage customs. As a result, many Western commentators are easily willing to believe that Southeast European peoples still live strictly by archaic tribal laws, which is not only obscure but also unscrupulous.

The problem is that honor is reified as a moral system instead of being considered as a political resource. In fact, whichever reference to blood mentality in relation to postcommunist turbulence in Albania, or to sexual violence in former Yugoslavia, becomes fundamentally a pure rhetoric. Nevertheless, as argued elsewhere, similar interpretations contributed to construct the Balkan image of Southeastern Europe in international representations with decisive implications in the global politics of regional affairs, including the advocating of the policy of non-intervention in Bosnia and the further containment of Western Balkans [45-47]. As a result, the insistence on international security contributed to install a fundamental political and ethical distance between the West and the so-called Balkan wars.

Reading the exposure of mass rape through the prisms of essential Balkan brutality and essential women's victimization made also possible to claim that while more Bosnians had been raped than Serbians, it was still the case that rapes have been carried out by all sides [54]. The problem is not that Bosnian and Albanian women were the only victims of rape, and the violence perpetrated against other women must not be minimized. However, there is ample evidence that in former Yugoslavia this type of crime was overwhelmingly committed by the Serbian forces and this was identified as a crime against humanity in the indictment of Serbs at the International Criminal Tribunal.

What is more, Serbian strategic use of rape representations for political purposes began in Kosovo before the first shot was heard in former Yugoslavia, when Serbian victimization and militancy found place in the symbolism of women's body. At that time, local Serbian activists in Kosovo and Belgrade-based nationalist intellectuals and clerics began to campaign against a growing Albanian majority in Kosovo, characterizing Albanian high birth rates as a conspiracy of sexual aggression and alleging a genocidal plan to exterminate Serbs by using rape to inspire terror. Many of the claims that Albanians might have started the very war of rape were not backed by factual evidence but were built up as popular rumors believed amongst Serbs in Kosovo [111]. Nevertheless, they were actually used later to detract international attention from the Serbian genocidal politics of mass rapes in both Bosnian war and Kosovo war.

Despite the many visibilities of wartime sexual violence, some "critical" feminist scholars do not take account of the apparent paradox of wartime sexual violence that has heightened visibility in some contexts and relative invisibility in others. They may even overlook the feminist concerns that violence against women in wartime remains largely invisible as a matter of political urgency and they discard explanations by the selective mobilization of rape narratives for nationalist propaganda. When feminist legal scholars argue for an alternative approach through a focus on "what actually happens during rape situations", considering variances and exceptions at a "level of detail with all the inconsistencies and complexities revealed", this cannot make it possible to imagine "a situation where rape is not inevitable" ([105]:161). In this situation, the sociological problem to be explained becomes the detailed experiences of violence, rather than violence and its instrumental links to gender and power, while wartime rape and sexual violence become relativized and ultimately wiped out. 
In particular, the feminist insistence that women of all ethnic groups were victims of rape perpetuated the perception and finally a position of "everyone is guilty", which turned out to be a moral obfuscation and the final fallback position of Serbian nationalism [112]. Actually, the moral relativism of generalized guilt allowed again a convenient avoidance of the stubborn fact that innocents suffered and their suffering was inflicted upon them deliberately. The legalist insistence to consider the social complexity that shaped individual experiences of the genocide, which is claimed to be glossed over in an approach to rape as an instrument of ethnic cleansing and genocide [105], becomes another instance of the same moral relativism. Similarly, the feminist insistence to subvert the political use of rape as an instrument of ethnic cleansing and genocide simply because this kind of argument is assumed to destroy the transnational solidarity of women [72], is nothing but an immoral relief of the genocidal politics of Serbian nationalism. Again, the humanrightist insistence to distinguish the short-term politics of forced impregnation from the long-term politics of community destruction, which is claimed to impinge on the human rights of children born of war rape [101, 102], may become inadvertently another attempt at the same moral relativism.

From the ethnographic record of ethnic conflict in former Yugoslavia, it can be observed that claims of opposed factions are often similarly phrased, revealing both the rules of the game and the degree to which actors are prepared to commit and tolerate deviations from the prevailing set of rules. Mutual recriminations about sexual atrocities and other violence against human rights, as Michael Herzfeld noted in other contexts ([113]:125), are evidence at least as much of shared symbolism as they are of real differences in the respective fates of embattled populations. This becomes especially clear in the meticulously intimate investigations of ethnographic engagement with the pragmatics of social interaction that turns abstract moral judgments into the objects of critical inquiry. Similarly, the historical anthropological approach reveals the long-term effects of kinship connections and matrimonial strategies, inheritance practices, moral norms, and instrumental ideologies. A combination of ethnography and historical anthropology to structural analysis may allow a new theoretical and methodological approach to explain the effectiveness of mass rapes as a military strategy of ethnic cleansing in former Yugoslavia to which we now turn.

\section{A morphodynamic approach to mass rapes}

Fieldwork apprehension and the acquired knowledge in anthropological theory may show how projected mythologies are determined by the gender construction of the world, while at the same time they are supported by a local cultural background. Nevertheless, it is important to work outwards from rape rather than inwards toward rape from a particular social system. We should examine rapes by their specific constellation of practices and discourses. A more specific and contextualized analysis must incorporate and situate theories of rape according to structural variations in ethnic relations intersected rather than overcome by gender relations. One of the most important achievements of both structural analysis and feminist approaches has been to reveal that gender is a structural feature of all-encompassing representations of the world. To think comparatively about rape in ethnic war, we must understand gender 
relationship to ethnicity in more complicated ways. Essentially, the reality of the world must be located in the meaning-production morphology of relations, structures, and values underlying the gender arrangement and gender construction within a sociocultural context.

Feminist scholars have forcefully emphasized that rape, as a forced sexual intercourse, is not a simple aggressive expression of sexuality, but rather a sexual expression of social violence. Similarly, it can be argued that marriage is not only a social institution of sexual relations, but also a sexual regulation of social violence and a sexual institution of social stability. Leaving aside many other ways in which political philosophers, legal scholars and religious specialists have viewed marriage, from a structural anthropological perspective, matrimonial strategies are intended to seal political alliances and conceal debts of blood, honor or money. Though normally a customary transaction of women exchanged between agnatic groups of men [114], by marriage several different kinds of rights are allocated. Marriage is a transaction and resulting contract in which individual partners are recognized by society as having a continuing claim to the right of sexual access to one another, while children are recognized as legitimate by establishing their legal parents ([115]:183).

There is quite a large literature on Southeast European social structures (see [116]) and almost all note that kinship terminological systems, marriage patterns and ideological cultural elaborations differed even between Slavic peoples. Unless we revert to old anthropogeographical stereotypes [117], it would be hard and outdated to bring these accounts into whatever might be a kinship morphology and family honor ideology of the Bosnian war and the Kosovo war in former Yugoslavia. Mass rapes during these conflicts may not differ essentially from mass rapes in other conflicts. On one hand, the dominant traditionalist-survivalist values of family honor ideology are not specific to Southeast European societies, and may exist in many parts of the world, despite steady changes in the World Values Survey cultural map [2], albeit in different ways linguistically. On the other hand, kinship and gender norms in one context cannot be generalized to explain ethnicized mass rapes in other areas, and there might be nothing specific in any context that does not obtain in areas with different kinship and gender norms. Therefore, the exploration of the specific cultural and ideological context of Albanian kinship morphology is aimed only as a comparative illustration of a more general process of the silencing of human agency, in particular women's agency, under the appearance of structural coherence.

The Albanian opposition between the tree of blood and the tree of milk did not indicate male descent and female descent, but always the male descent either in paternal or in maternal line. Similarly, the composite term of gjak e gjini, literally "blood and gender", indicates a real recognition of the membership to the corresponding paternal or maternal line series [33]. In turn, the distinction between blood tree and milk tree makes it possible to articulate kinship to other political and ideological systems [32]. Two patrilineal groups that share the same milk tree are in the position of in-laws or allied affinal partners (Fig. 1).

The meaning that Albanians give to a relation of matrimonial alliance and affinity systematically included a structural relation that was often a parallel close relationship of friendship and hospitality, which is contracted between two patrilineal groups, or blood trees, aiming to share the same milk tree. Generally contracted on the model of the relations of matrimonial alliance or filial adoption, these notions often bring 


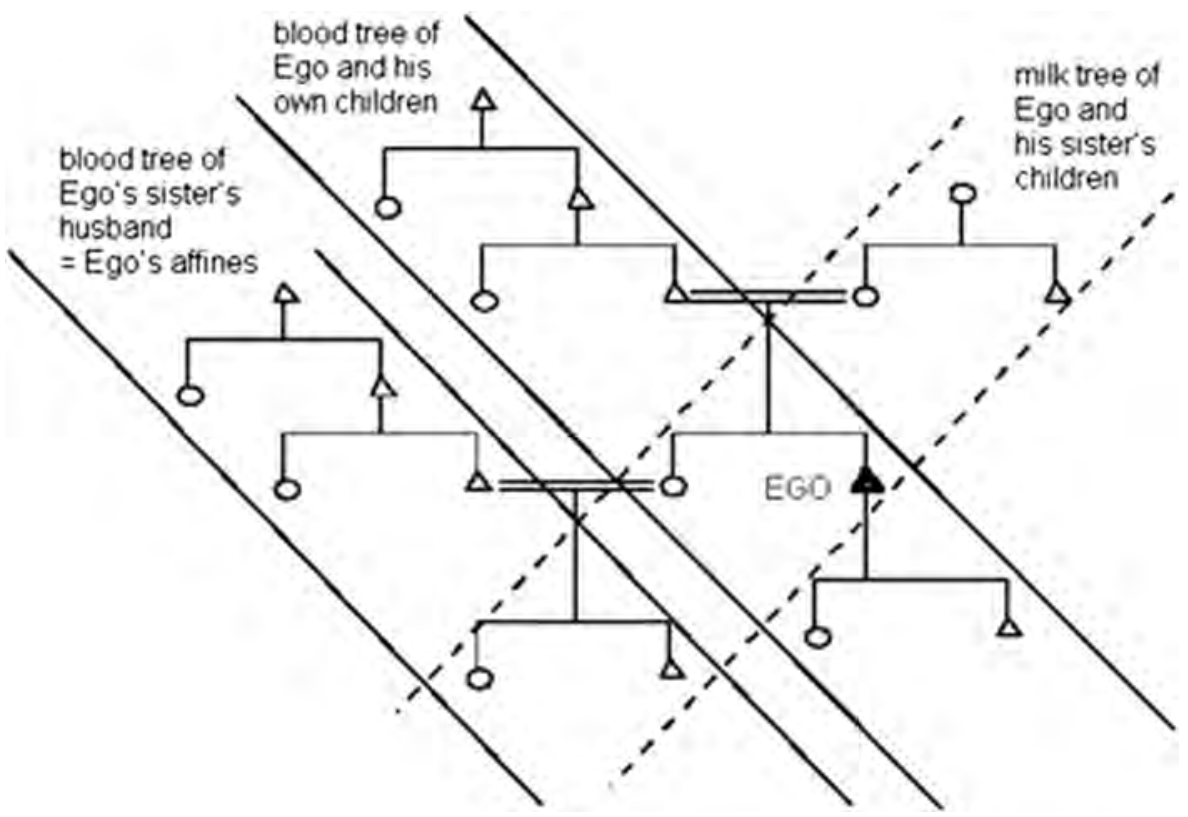

Fig. 1 The orthogonal encounter between a milk tree and a blood tree does not yield a marriage alliance but the convergence of Ego's paternal and maternal ascending lines: Matrimonial alliance is a parallel close relationship contracted between two blood trees aiming to share the same milk tree

symbolically together the intrinsic values embodied in two different blood trees. However, hostility and feud are also established the same way between two different blood trees against a distance of conflict, often forcefully emphasized by the difficulty or the refusal to share a milk tree. The term that expresses the feud in Albanian is once again gjaku, the "blood", while the very notion of vengeance is expressed by a descriptive term, gjakmarrje, literally "blood taking", and the term gjakësi properly signifies the blood feud as a "relation of conflict which provokes bloodshed in the group".

Definitely, both marriage and vengeance rest on the symbol of blood and both are institutions that give shape to alliances. If marriage created a network of alliances and divided society in exogamous groups, vengeance also created a continuously moving scenario in which memberships and strategic alliances constantly coagulated the consistency of agnatic groups. Similarly, while marriage produces the alliance of one blood to another blood, the blood that claimed alliance is what was poured for the honor of the family and which demanded the obligation of vengeance. Clearly, matrimonial affinity and hospitality, on the one hand, and feud vengeance and hostility, on the other, were interchangeable categories insofar as they were always relations of mutual obligation and constraint (Fig. 2).

A relation of matrimonial affinity and hospitality was experienced as a relationship of friendship and solidarity just as a relation of feud vengeance was lived as a relationship of hostility. Yet, if matrimonial affinity and feud vengeance were opposed to one another as much as many other structural modalities of association or dissociation between different agnatic groups, friendship and hostility were part of the same opposition. Matrimonial affinity and feud vengeance, friendship and hostility were only 


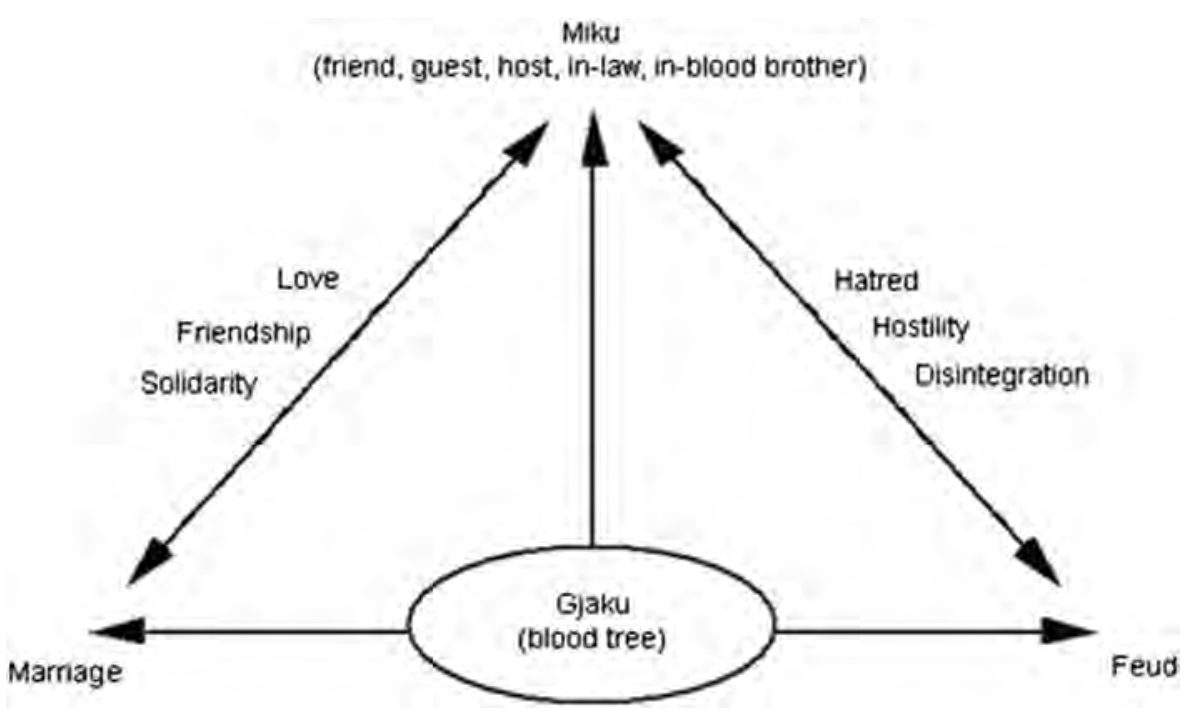

Fig. 2 Marriage and feud ambivalences

different expressions of a single and unique structural relationship. Definitely, the whole of social relations and values remained placed under the sign of ambivalence. In this sense, at a more empirical level, emotional sentiments as well as social relations and values of affinity, friendship, and hospitality, must have something in common with the relationship of love and solidarity to hatred and disintegration. Precisely this kind of structural ambivalence may allow a new structural model to explain the effectiveness of mass rapes as a military strategy of ethnic cleansing in former Yugoslavia.

Typically, rape in the ethnic conflicts of former Yugoslavia was a transaction of women exchanged between competing groups of men, but also an enforced transaction that was intended to break any political alliances and signify a definite ethnic cleansing of territory and community. In this case, the political significance of rape is aimed to substitute the tree of blood legitimated by marriage for another tree of blood that, although illegitimate, is construed following the same structural pattern. From the position of structural logic, marriage becomes possible by the means of matrimonial alliance that is supposed to bring love, friendship, and solidarity. In the same way, rape can be defined as a confrontational misalliance that becomes possible by the means of war, and which would necessarily induce hatred, hostility, and disintegration.

During the Bosnian War, mass rape campaigns were undertaken with the express purpose of impregnating women and forcing them to bear children. The existence of deliberately created rape camps was reported, where Serbian forces perpetrated public rapes in front of numerous witnesses, villagers and neighbors [118-120]. The reported aim of these rapes was to impregnate the Bosnian and Croatian women held captive in an attempt towards ethnic cleansing. Some military camps served exclusively as rape camps, such as the one at Foça, where the Serbian policies of mass rape, forced impregnation and forced maternity were implemented. Throughout Bosnia-Herzegovina, the camps were set up in nearly identical ways-they even had the same layout and patterns of rape [121]. Women were detained and forced to endure repeated gang rapes 
intended to impregnate them and were repeatedly told that they were being raped in order to "plant the seed of Serbs in Bosnia" and give birth of a new generation of Serbian children [102]. Narratives told by hundreds of women held at camps around Bosnia suggest that women were raped repeatedly and once impregnated they were held in detention until abortion was no longer an option ([122]:110-111). Forced to carry Serbian children through repeated rape, these women were only released slightly before the birth of a child conceived of rape ([55]:77).

During the Kosovo War, thousands of Kosovo Albanian women became victims of the same patterns of sexual violence as during the Bosnian War. Virtually all of the sexual assaults documented in Kosovo were gang rapes, with the majority of the perpetrators being Serbian paramilitaries, but also including Serbian special police and Yugoslav army soldiers. ${ }^{6}$ In addition, some women were forced to retrieve their bridal attire from their dowry chests and wear it while dancing in a circle in a courtyard, before they were raped. ${ }^{7}$ Assuming that the male kin, who were fighting in the hills, could see what was happening but were unable to come to the women's rescue, the rape of women in their bridal dresses in Kosovo was aimed to emphasize the dynamics that controlled Albanian women's sexuality as the site of men's own sexuality and power. In all cases, the accounts from both surviving victims and convicted soldiers provide additional evidence that implementing the policy of forced impregnation and maternity were the strategy dictated by Serbian authorities and generally perpetrated to ensure that the women of the adversarial ethnic group will give birth to children of their enemies.

Through the implementation of policies of forced impregnation and forced maternity, rape served not merely to torture or degrade, but also to "occupy the womb" of the women of the enemy [122]. Remarkably, when a woman was raped in this war, the ethnic-national membership of the rapist and the possible foetus became the focal matter of concern for the ethnic-national community of the raped woman, dismissing both her and the crime committed against her. Reports focused almost exclusively on the crimes of the "other" side, creating a context for "our" women's womb and body to be considered as an "occupied" territory, which posits a "sexual geography of ethnicity" that connects rape to exclusive territoriality [107]. In such a context, public debates focused on whether they should be allowed to have an abortion so that they do not carry "the enemy's seed in their wombs". Women's right to abortion took the shape of an almost military intervention and the question of the right to abortion became an important component in the military strategy of "territorial" cleansing [124]. Commonly, the notion of cleansing is also related to abortion both in Serbian/ Croatian/Bosnian language (kiretaža) and in Albanian language (spastrim). With regard to "territorial cleansing" and "ethnic cleansing" as a newly-conceptualized military strategy of genocide in war in the former Yugoslavia, women in the region will easily understand the painful meaning of the term since cleansing is above all a part of women's experience.

\footnotetext{
${ }^{6}$ Human Rights Watch, Serb Gang Rapes in Kosovo Exposed, 20 March 2000 (https://www.hrw. org/news/2000/03/20/serb-gang-rapes-kosovo-exposed), Human Rights Watch, Kosovo: rape as a weapon of ethnic cleansing (https://www.hrw.org/legacy/reports/2000/fry/index.htm).

${ }^{7}$ Information reported by Nita Luçi
} 
This is not, however, to understand women's experiences of rape and marriage in a binary and rigid structuralist relation. There is necessarily a problem with this argument that is inspired from Aristotle's logic of analogy (Rhetoric 1402b15, Pr.An.69a1), which set the stage for all modern theories and sophisticated analyses of analogical reasoning. In this case, Aristotle's logic of analogy cannot be valid and analogical reasoning of any type of thinking that relies upon an analogy or comparison between marriage and rape that highlights respects in which they might be thought to be similar will be misleading (Fig. 3). Following Aristotle's logic, the analogical argument as an explicit representation of a form of analogical reasoning may take some accepted similarities between marriage and rape to support the conclusion that some further similarity may exist. However, this argumentative form is not a complete inductive reasoning as it "does not draw its proof from all the particular cases" (Pr.An.69a15), but requires an additional and deductively valid syllogism as the final step, which is arguably provided by the application of Lévi-Strauss's canonical formulation.

On empirical grounds, if the metaphysical ambivalence of marriage may bring at the same time love and solidarity as well as hatred and hostility, in the case of rape, even though structurally construed like marriage, there is no ambivalence, because there is no way that rape can bring other than hatred, hostility, and disintegration. Actually, rape is unspeakable, unthinkable, and beyond human understanding. We can only offer a breaking down in abstract mathematical terms as an inferential process deductively valid to account for the effectiveness of mass rape as a military strategy and political instrument of ethnic cleansing in former Yugoslavia. To this aim, a reformulation is proposed of the catastrophist model suggested by Lévi-Strauss for the structural study of myth.

After some preliminary work on mass rapes during the ethnic wars in former Yugoslavia $[12,73,125,126]$, it may also be argued that the heuristic relevance of Lévi-Strauss's notion of canonical formulation could reasonably stand for understanding their effective politics as an instrument of ethnic cleansing. Based on Lévi-Strauss's morphodynamic theory, categories like terms and functions are

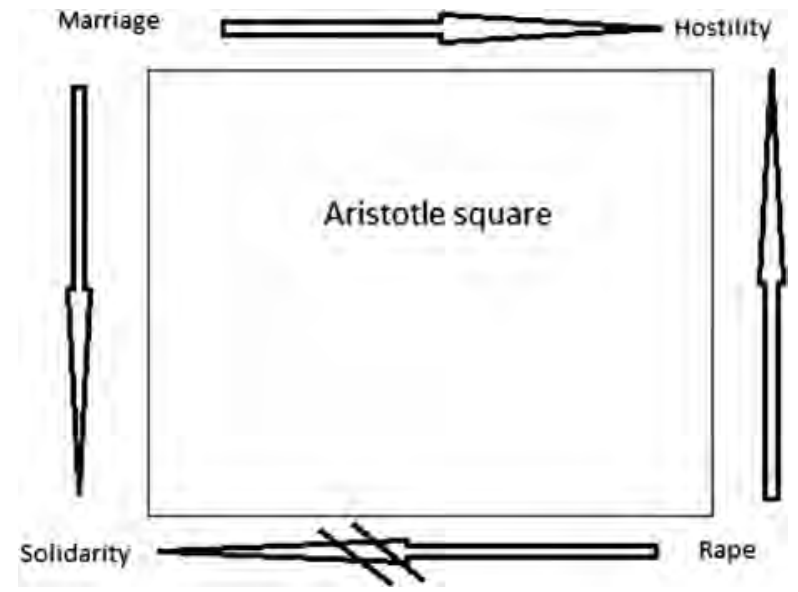

Fig. 3 The impossibility of analogical reasoning in the case of Marriage and Rape 
considered as ontology-specific renderings of more general categories. They map onto categories like langue and parole (Saussure), kind and index (Peirce), competence and performance (Chomsky), status and role (Linton), power and its exercise (Hobbes), and even essence and appearance in certain philosophical traditions. In the context of ethnic conflict, such specific categories need to be articulated in relation to a broader set of categories and resolutely theorized in terms of their mutual transformations. Namely, transformational variables of indexical terms of either marriage or rape, which are qualified with different instrumental roles or function values of group politics, can be singled out in specific collective instances of social behavior as they are enacted and practiced in articulation with conflict ontologies and cultural ideologies.

Rape carried out by the Serbian forces was not isolated acts or a secondary effect of the conflict but deliberate and organized crimes against populations, an instrument of terrorization as part of a systematic policy and genocidal campaign of ethnic cleansing [53-55, 121, 127, 128]. The bodies of "wrong" women, the female representatives of adversary ethnic groups, served as the main target of these dehumanizing acts. In this way, women's bodies constituted the battlefield where men communicated their rage to other men. The primary purpose of rapes as a weapon of war was to cause profound humiliation, degradation, and intimidation to ensure the survivors would leave and never return [129]. It served to destroy cultural and social ties of the victims and their communities by inflicting humiliation and shame [56] and it was "perpetrated with the conscious intention of demoralizing and terrorizing communities, driving them from their home regions, and demonstrating the power of the invading forces" ([130]:34). Arguably, to establish a comparable point of reference for the Serbian genocidal politics of mass rapes in former Yugoslavia, "not even the Nazis managed to invent a way to turn the biological process of gestation into a weapon of annihilation" ([55]:91).

Serbian gang rapes in Bosnian detention camps always involved a performance for a public audience, while some rapes were not only publicly performed but also filmed with video technology. Whether these films were sold as pornography for mass consumption like news and entertainment, which was also used to whip up a popular frenzy for the Serbian war effort, is a notorious matter of dispute between activists and scholars. As a rule, they are closely tied to the propaganda efforts of either Serbian, Croatian or Bosnian government, or to different strands of feminist activism aiming to promote their own agendas $[131,132]$. It is quite possible that polemicists and demagogues have circulated with great delight some grotesquely exaggerated and made-up horror tales as empirical facts. The alarming claim remains, however, that "the world has never seen sex used this consciously, this cynically, this elaborately, this openly, this systematically with this degree of technology and psychological sophistication, as a means of destroying a whole people" ([60]:27). This remains true in spite of many efforts that actually paralleled Serbian propaganda of "everyone is guilty", which has been quite common for a long time in approaching the ethnic conflicts of the 1990s in former Yugoslavia.

Apparently, in this context, an innate or learned psychological bias may lead members of ethnic groups to discount or ignore their own involvement in 
producing ethnic conflict, so that the other should take all the blame. Following Tajfel's "social identity theory" [133], if people have an innate desire for selfesteem, then they may be irrationally reluctant to believe that members of their own group, especially their leadership, could be responsible for reprehensible acts. The astonishing denials encountered from Serbian intellectuals at home and abroad confronted with evidence of genocide and crime against humanity both in Bosnia and in Kosovo is a good example of this mechanism at work ([134]:854). ${ }^{8}$ In this puzzle, it is hardly surprising that many commentators remain shocked at mass acquiescence to the machinations of their own national elites to minimize war atrocities, while claiming that they engaged successfully in "psychological warfare" (e.g. [97]:228).

In turn, among interviewed women a general concern was that the issue of rape should not be stressed at the expense of the Serbian campaign of slaughter and genocide against the civilian population of Bosnia and Kosovo, male and female alike. Very often "they didn't want in any way to let the rape overshadow the real problem, which is the extermination and execution of thousands and thousands of men and women" ([135]:119). A participant in a New York conference on Bosnia said that as a Bosnian woman she felt that "the international emphasis on rape was inappropriate, because all Bosnian women were victims: they lost their homes, their sons, their husbands, their jobs, their lives, and whether they had been sexually assaulted or not was not really the most important problem" ([66]:35). Some feminist had reproached Albanian women in Kosovo for having denounced only ethnically motivated violence ([136]:173), but a Kosovo activist said they could not have done otherwise as "they were experiencing a double violence against their men and themselves" ([67]:641).

The International Criminal Tribunal for the Former Yugoslavia did not treat explicitly the mass rapes as genocide. However, in the case related to the Bosnian War decided by the International Court of Justice, the verdict held that the Srebrenica massacre was a genocide and that Serbia had committed a breach of the Genocide Convention. The World Court concluded that the acts at Srebrenica "were committed with the specific intent to destroy in part the group of the Muslims of Bosnia and Herzegovina as such, and accordingly that these were acts of genocide" committed by Serbian military forces. ${ }^{9}$ The World Court heard the requests to include the practice of terrorizing the non-Serbian population, the infliction of pain and the administration of torture as well as the practice of systematic humiliation into this category of acts of genocide. It also put "a particular emphasis on the issue of systematic rapes of Muslim

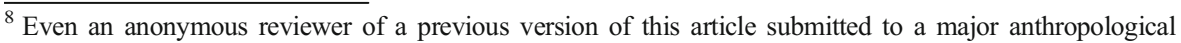
journal went to considerable length to discard genocidal rape as a "pure rhetoric, not a legal category", to disparage most sources as not credible, written by people not experts in former Yugoslavia or competent in Serbian/Croatian/Bosnian language, and to minimize figures of rapes and other casualties. As expected, they discuss rape and genocide for only to deny them both in "the pretty modern European society" of a country they cherish. Their conclusion could not be but "there is actually almost no good evidence for the proposition that there was a campaign by Serbian military or political leaders to rape mass numbers of Bosnian women, even less that there was a campaign to impregnate them." Finally, all this makes it sound as though mass rape and genocide in former Yugoslavia were a children's game in the grade school playground.

${ }^{9}$ International Court of Justice, Case concerning the Application of the Convention on the Prevention and Punishment of the Crime of Genocide (Bosnia and Herzegovina v. Serbia and Montenegro): Judgment, 26 February 2007, ICJ General List no. 91, p. 108, § 297, http://www.worldlii.org/int/cases/ICJ/2007/2.html.
} 
women, perpetrated as part of genocide against the Muslims in Bosnia during the conflict". ${ }^{10}$

The strategic use of mass rape is well suited for campaigns that involve ethnic cleansing and genocide, as the objective is to destroy or forcefully remove the target population. Mass rape instills terror in the civilian population and reduces the likelihood of return and reconstitution $[137,138]$. From the organized and systematic nature of the mass rapes of women both in Bosnia and in Kosovo, many have concluded that these rapes were part of a larger Serbian campaign of genocide [139]. For many, the Serbs, with "the complicity of Serbian intellectuals" [140], and sometimes with that of international networks of experts and institutions [141], were carrying out a policy of genocidal rape against other ethnic groups in former Yugoslavia.

For the purpose of this argument, the permutational relation between indexical terms and function values of both rape and marriage may be productively mapped onto a catastrophist model following Lévi-Strauss's morphodynamic theory. Indeed, not only war is a catastrophe, but also rape in war is a catastrophe on its own [142]. Accordingly, we may offer a catastrophist model to conceptualize rape by means of a canonical formalization in which the solidarity role of marriage will stand to the hostility of rape as the ambivalence of marriage stands to the rape politics of an unspeakable and unthinkable solidarity ${ }^{-1}$, or "anti-solidarity":

$$
\operatorname{marriage}_{(\text {solidarity) }}: \operatorname{rape}_{(\text {hostility) }}:: \operatorname{marriage}_{(\text {hostility })}: \text { solidarity }^{-1} \text { (rape) }
$$

Still, this is not only to provide a new description, however elegant, and nothing more. In a quadratic equation of this type, the generative virtues of the so-called "double twist" of the canonical transformation in the structural study of myth imply two conditions internal to canonical formalization. According to Lévi-Strauss, a formulation of this type reflects a group of transformations in which it is assumed that a relation of equivalence exists between two situations defined respectively by an inversion of terms and relations, provided that one of the terms is replaced by its opposite and that a correlative inversion is made between the function value and the term value of two elements ([14]:252-253). Indeed, here rape is replaced forcibly by marriage, its opposite, and a correlative inversion is made between the functional ambivalence of marriage and the hidden ontology of enforced rape function.

\footnotetext{
${ }^{10}$ Ibid., $§ 298$. The World Court found (although not unanimously) that Serbia was neither directly responsible for the Srebrenica genocide, nor that it was complicit in it. However, the Court's Vice-President appended a dissenting opinion to the Judgment of the Court, stating that "Serbia's involvement, as a principal actor or accomplice, in the genocide that took place in Srebrenica is supported by massive and compelling evidence". In his opinion, the involvement or implication of Serbia in the genocide that took place in the 1990s in Former Yugoslavia was "both more serious in nature and more extensive in territorial scope than the mere failure to prevent genocide in Srebrenica conveys". This implies that the charge that Serbia was "responsible not only for its failure to prevent genocide but for being actively involved in it either as a principal or alternatively as an accomplice or by way of conspiracy or incitement would in all probability have been proven had the Court ... followed a different methodology", which could also improve "the high standard of proof or the rigor of its reasoning". See: International Court of Justice, Case concerning the Application of the Convention on the Prevention and Punishment of the Crime of Genocide (Bosnia and Herzegovina v. Serbia and Montenegro): Judgment, 26 February 2007, Dissenting Opinion of Vice-President Al-Khasawneh, p. 254, § 30-34, http://www.icj-cij.org/docket/files/91/13689.pdf.
} 
Now, for a catastrophist operation of this kind to take place, the very idea of canonical relation requires a third operating condition, which is external to canonical formalization. In Lévi-Strauss's structural study of myth, this condition remains often implicit and never articulated [27]. In all cases, it is expressed as the necessity of the crossing of a spatiotemporal boundary, defined in territorial, ecological, linguistic, cultural, social, or other terms, but which is always a boundary condition in mathematical sense, required to be satisfied at the boundary of a topological domain in which a set of differential equations is to be solved. The catastrophist operation that requires a boundary condition of this kind is claimed by Lévi-Strauss to be important in determining the mathematical solutions to various mythical problems. Namely, a series of variations inherent in the myths of a given people cannot be fully understood without going through myths belonging to another people, which are in a relation of inverse transformation with the formers. Eventually, as shown elsewhere [6, 7, 12], the requirement of a boundary condition in canonical formalization can anticipate the very politics of an ideological agency and discursive practice for the lack of which structural analysis has been undeservedly disregarded.

\section{Cultural activism as a boundary condition}

Mass rape cannot be reduced to the psychological attributes of individual aggressors or any aggregate of organizational factors in armed groups, neither to the reified cultural traits of a supposed war prone people. All these arguments may be partially attempts at scholarly interpretation but presumably they are similar to those used by the perpetrators themselves, both at the time and afterwards, as legitimation or apology of the genocide perpetrated. Mass rape must be understood in relation to specific social structures, discursive practices and political situations.

As appalling evidence accumulated, it became increasingly clear that many dimensions of Bosnian and Kosovo experiences should be linked to the impact of globalization and the consequences of disintegration in the former Yugoslavia than to aggressive misogynistic masculinity in general and atavistic Balkan brutality in particular. At the root of the violence, largely instigated by a modern mechanism of war propaganda, remained the conflict fought out between the leading elites of ethnic-religious and political entrepreneurs [143]. The highly antagonistic contents of the politicized ethnic labels of Bosnian, Serb, and Croat, or Serb and Albanian in the 1990s are a result of the conflicts and wars following the economic collapse and the breakdown of the Yugoslav state rather than the other way around [144]. Even when traditional ideas of kinship and ancestry were mobilized to construct the ethnic-religious other, they were used in a new political context particular to post-socialist Yugoslavia.

While broad structural forces and socioeconomic processes can be seen as necessary conditions, an alternative interpretation of ethnic violence considers the content and boundary rules of ethnic categories as constructed by the actions of individual actors seeking various ends. If individuals are viewed as the agents who construct ethnic identities, then constructivist explanations for ethnic violence tend to merge with a rationalist or strategic choice approach. In particular, they emphasize elite manipulation of mass publics, but also the violence stemming from ethnic interactions on the ground when the individual actions of mass publics produce, reproduce, and contest the content 
and boundaries of ethnic categories ([134]:853-857). Indeed, it is striking and no coincidence that virtually every self-identified constructivist who has written on ethnic violence has tended to blame elite machinations and politicking. The political dynamics between moderates and extremists are also an important part of the violent story in former Yugoslavia. Much of the violence is seen as induced by extremists and ultranationalists to justify their ultra-extremism both at home and abroad, pushing moderate leaders into atrocities or portraying themselves to the rest of the world as moderates holding back the ultras ([123]:355).

In contrast, another interpretation locates the process at the level of supra-individual things such as Foucault's “discursive formations" [145], or Geertz's "cultural systems" that have their own internal logic or agency of culturally specific ways of thinking, talking, and acting [146]. This symbolic approach suggests that the development of discursive formations and cultural systems can set one group in opposition to another or predispose them to see the other as a threat or natural subject for violence, independent of any more material basis for hostility ([134]:851-853). In practice, discursive formations or cultural systems seen as the agents of identity construction tend to merge with older culturalist accounts that portrayed cultures as highly bounded, internally coherent, and static entities, which strongly determine the behavior of the members of the groups they constitute (e.g. [147]). The newer constructivist culturalism rejects the idea that cultures and the discourses that shape or define them are bounded, coherent or static, but it retains the idea that discourses strongly shape ethnic identities and determine individual actions. These arguments tend to portray culture in a way that borders on primordialism, in that people are continually made and remade by discourses that are essential properties of ethnic groups.

However, despite the apparent primordialism of discursive logics, the rigid divide in methodological debates between rationalist and culturalist accounts can be bridged. Strategic theories linking elites or publics to ethnic violence and discursive theories linking discourses to violent behaviors are all constructivist in the sense that they posit the content and boundaries of ethnic groups as produced and reproduced by specific social processes ([134]:874). A discourse is a set of arguments employed by some actors either in justifying or in intensifying their actions or a policy that is pursued for some reason. Used in this way, discourses are more strategies than supra-individual forces with their own internal logics to determine actions and events. In the case of mass rapes perpetrated by Serbian military forces in Bosnian and Kosovo wars, we may focus not so much on the discursive impact of honor ideology on sexual violence as on the political construction of sexual violence by the strategic use of discursive ideologies. Arguably, mass rapes and sexual violence against women might have fitted the political needs of warlords, who are then responsible for publicly coding them as honor violence ethnically targeted. This coding itself had incendiary implications and served to perpetuate or foster cases of larger scale sexual violence. What is significant is not that ethnic identities are constructed through violence, but that sexual violence against women is politically constructed as ethnic violence against women's community.

The politically destructive intention of rapes perpetrated by Serbian military forces during the Bosnian War was undoubtedly to eliminate the Bosnian and Croatian adverse communities just as during the Kosovo War was to eliminate Albanians. However, this elimination was aimed to work most effectively through the community's own self-destruction as a social and ethnic group. Rape becomes a 
particularly patent form of social destruction in patrilineal societies in which gender ideas take their particular meanings within a prestige structure of honor and feud.

Honor is a basic value in Southeast-European societies, and any explanation of household organization and gender relations must take account of this cosmologicalphilosophical element, which is necessarily activated to link exaggerated values of male supremacy to mechanisms of female suppression. The traditional perception of women was rooted in women's perceived diminution of the masculine ideal as an independent and self-sufficient honor. The more the males were construed to be omnipotent, the more the ostensibly insignificant females threatened this omnipotence, which involved a problem of control over women. The ability of a household's men to control their women was one of many indicators of the household's strength. Women's chastity, indeed, provided one of the main concepts in the chain of men's rights that made up the key ideal of family honor on which the blood-feud rested.

Honor and shame have been discussed as "two poles of an evaluation" in Mediterranean societies [148]. Not surprisingly, in Southeast European societies, people also came to realize and assert explicitly that women affected a man's prestige. In Greek mountain communities, "the manliness of the men in any family protects the sexual honor of its women from external insult or outrage, [while] the women must have shame if the manliness of the men is not to be dishonored" ([149]:271). Ethnographic accounts of South Slavic communities have also constantly shown that evidence of lack of control over women would indicate weakness and possibly reveal the men's vulnerability to other external challenges ([150]:254-255). Among Albanians, it was the importance of upholding family honor and prestige which frequently would lead to a blood-feud and, indeed, helped to perpetuate the tradition of blood-feud.

In the public opinion of local community, the essential element in marriage was virginity of the bride, expected of all unmarried women, as was her chaste behavior as a married woman, a stipulation that ensured that her offspring will indeed be genuine heirs of her husband's lineage. With such a conception, society rendered itself particularly vulnerable to potential confusion created by infidel women. While it might be sufficient reason for a bride to be repudiated by the groom's house if she was found not to be a virgin, by "sleeping around" (bredhur), women could literally mess up the whole neatly ordered patrilineal system. It follows logically that adultery was punished most severely, whereby the offended male, be it father, brother or husband, had the right to kill both woman and lover ([151]:230). Indeed, one occasion when a sister was never avenged was when she was taken in adultery and killed together with her paramour. The woman would not be avenged, as she would be thought to have acted against the honor of her own family. The high valuation of chastity is therefore bound up with the ideal of family honor, and women were seen only as contributing to or detracting from family honor, not as individuals with virtue of their own right.

Inasmuch as the stance of the group's invulnerability represented by its family honor was crucial to its competitive situation with other groups, it was obvious that the stance of women's adultery, making a "laughingstock" of the moral integrity and honor of the family, would be very damaging to men attempting to play their roles out in the public arena. In these conditions, it becomes self-evident that in the case of raped women, the shame of victimization would be far worse than the perpetration of the crime. Commentators of mass rapes during the Bosnian war and the Kosovo war in former Yugoslavia might ponder that these assumptions must already exist to support a policy 
of mass rape, for "if they do not, this policy loses its coercive power and may not be as successful in driving families apart or securing ethnic cleansing" ([102]:564). The fact that both victims and perpetrators willingly forward such assumptions as a short expedient to explain the atrocious experience of mass rapes should at least make commentators and social scientists curious about them. There is no evidence of such an awareness and seldom is any account taken of the possibility that these assumptions could be deliberately activated.

Feminist scholarship has mapped the propaganda value of rape stories at various points in armed conflicts. In former Yugoslavia [107], as elsewhere [152], rape narratives were deployed in different ways to construct shifting conceptions of group identity. By recognizing as criminal different types of harm, the legal categorization of war crimes provides also a language by which the Tribunal can identify and witnesses can testify to their experiences of legally recognized harm [77]. However, a typical legal academicism and intellectualism prevents feminist legal scholars to see that it not the Tribunal recognition of rape as an instrument of ethnic cleansing and genocide that places gender and ethnic identities into particular positions within a gendered and ethnic grammar of violence ([105]:155), but the other way around. It is political urgency and the selective mobilization of rape narratives for nationalist propaganda that uses the rules and structures of a gendered and ethnic grammar of violence to make rape a weapon of war, which deliberately assign people to essential positions of gender inequality and ethnic divisions. This means that gender and ethnic identities do not preexist violence and violence is not mapped simply onto existing historical identities and ethnic divisions. For the violence to be effective, the discursive activation of a gendered and ethnic grammar of violence must create and essentialize historical identities and ethnic divisions in the first place.

A major concern of contemporary anthropological scholarship on gendered wartime violence, in former Yugoslavia [103, 104] or elsewhere [84, 153-156], is the role of traditionalist and nationalist discourses, which is mathematically identified here as a logical necessity by the requirement of a boundary condition in canonical formalization. Actually, in a context in which mass rape was deliberately used as a possible instrument of ethnic cleansing, everything happened as if the activation of a specific political and instrumental agency was necessary for the notorious effectiveness of mass rape to take place. This kind of ideological agency can be shown to promote and put forward the cultural assumptions specific to a given group. During the Bosnian war and the Kosovo war in former Yugoslavia, it was provided by the increasing role of deliberate discourses to burst moral order and social morphology in the first place, precisely by bringing to the fore the destructive workings of family honor and blood ideology. Indeed, the mass rapes of women were intended to forcefully instill a kind of shame and disgrace as a social pollution that should bring necessarily the disorder and break-up of the social system of any group in its totality. Typically, at war, such a social pollution and catastrophic disorder is termed in Albanian with a generic term for "total killing", shfarosje, which means literally "kinship uprooting".

The systematic rape of women during the Bosnian War and the Kosovo War may have carried further-reaching repercussions than the initial displacement of rape victims. Stress, caused by the trauma of rape, coupled with the lack of access to reproductive health care often experienced by displaced peoples, lead to serious health risks for victimized women $[157,158]$. In addition, the discursive practices that 
surrounds the issues of rape during wartime frequently lead to pervasive discrimination against specific social groups, outrageous acts of violence against women, and neglect of children who are born of rape during wartime [102]. In 1993, when people worldwide were talking about raped and impregnated women in former Yugoslavia, almost nothing was said about these women as suffering beings. Women who survived these horrendous experiences have undergone egregious human rights violations, but their experiences were overshadowed by political and military discussions about wartime rape as a method of ethnic cleansing.

In particular, the maternal agony of women who bore children conceived from war rapes devastated women and had more serious consequences for their future than any other aspect of rape. Moreover, the innocent children born of rape during wartime or in the war's aftermath, because they represent or stand in for the perpetrators of the crime to their mothers, are frequently punished in terrible and unjust ways. These children are often viewed purely as other, despite the fact that members of their mothers' ethnic groups usually raise them. The father's ethnic identity and the shame surrounding the conception are the only factors that matter. For those women who are raising their children, their anger and resentment may give rise to abuse. Many women "attempt to kill their babies at birth in a reaction that, speaking strictly in terms of the mother's psychological well-being, might even be considered healthy" ([102]:571). The high rates of infanticide and the acceptance of these incidents as natural reflect the ways in which the rights of these children are severely undermined [101]. Further, the language used to describe and label these children is extremely derogatory. As the child born of rape in France during the First World War was called "the child of the barbarian" [159], media reports showed that children born of rape in Bosnia are called "children of hate" or in Kosovo they are known as "children of shame". All the labels connect the children to their fathers both rapist and enemy, a legacy they can never escape. As these children grow up and become aware of the fact, life becomes even more difficult.

Returning to a paraphrased Lévi-Strauss's terminology from The Raw and The Cooked [15], the unspeakable political effectiveness of mass rapes is forwarded to account not just for a "raw" madness of cultural norms and values. It is mainly the twist of a "cooked" evil of ideological agency acting as an instrumental politics of ethnic cleansing during ethnic conflicts in former Yugoslavia and elsewhere. The cultural activism of family honor and blood ideology makes it possible afterwards for family norms and values to be converted into ethnic-religious ideology, for ethnicity to be converted into nationalist consciousness, for this consciousness to become organized into conflict, and for organized nationalism to become militarist, masculinist, misogynist, racist, and violent.

The cultural activism commonly obscures another important fact of a purely ideological dimension. The cultural myths and ideologies of honor and blood associated with patrilineality are often conflated with the actual practices of patriarchy. Many commentators (e.g. [160]), including the International Tribunal record (see [106]), have too easily assumed that the patriarchal language and discourses that symbolically support patrilineality result uniformly in outcomes and practices that they simply reify as patriarchal. Both the myth of many children and the family myth of honor and blood within the so-called lineage structures of the supposed patriarchal Albanian family are commonly constructed and conveyed in academic writings, the media and stereotyped opinions. However, as shown elsewhere [1], the ideological construction of these myths 
can be invalidated if we take what is put forward as empirical evidence to be nothing more than a strong cultural activism where both women and men are subjugated to the reproduction of social norms and values.

More than anything else, cultural pressure aims at limiting Albanian women to their childbearing function and Albanian men to their protecting function. Incidentally, such cultural pressure is activated deliberately and instrumentally when the bloody honor of men might be shown to have been sullied because of their women being raped during the ethnic conflicts in former Yugoslavia. In this case, we may suggest that rape acquires an immediate political function because it is sufficiently clear that the logic of family relations, based on a highly patriarchal model of family ideology where honor is central and a generator of violence, strongly binds the production of male subjects to ethnic politics.

Some human rights scholar are consumed with the distinction of mass rapes in former Yugoslavia between the short-term politics of forced impregnation and the long-term politics of community destruction. They naively believe that if the intent is to actually subjugate women to gang rape, impregnate them and force them to bring pregnancy to term, rape is not being used for ethnic cleansing or genocide and it is inappropriate to describe the politics of mass rapes as an instrument of ethnic cleansing and genocide $[101,102]$. In this argument, the paramount assumption underpinning the human rights protection of children born of war rape is that identity cannot be biologically and paternally given. Biology cannot exclusively matter in determining identity because the father cannot exclusively transmit his own identity to the child. In other words, in constructing identity, the maternal contributions, both genetic and cultural, cannot be marginal and the women cannot serve as vessels that impart paternal identity.

However, to assume that the people themselves do not know what human rights scholars suppose to know better also allows a convenient view of irrational people, or at least a state of ignorance of peoples, regarded as utterly primitive and which could even be presented as an indicator of their backwardness. As shown elsewhere [34, 161], this might have been the position of many early anthropologists who supposed that the peoples they observed have the ignorance and simple-mindedness of young children. What evolutionists thought on the whole, as Malinowski did believe some time later [162], is that primitive peoples were unaware of the physiological process of procreating a child. The explanation has nothing to do either, as more recent anthropologists are too quick to believe ([163]:87), with those sorts of "obvious" or "common-sense" reasons based on the application of interpretive grids that ignore the biochemical nature of impregnation.

As the "virgin birth" debate initiated by Edmund Leach showed, whether some peoples were truly unaware or simply claimed to be unaware of the appropriate men's and women's roles in procreation are by no means the result of ignorance or innocence, but they proceed from a very subtle ideological argumentation [164]. The ethnographic evidence generally leads to the conclusion that such purported ignorance is founded on the expression of certain ideological beliefs. In patrilineal societies, the biological principle of blood ( $g j a k u)$ is ideologically worked out as to be assumed as being transferred from father to son, and this ideological elaboration must have brought these people to take a view of the person strongly rooted in fatherhood [165]. If we listen to Albanians, for instance, we shall have to acknowledge that they construe identity as a matter of showing forth what already lies within. We find paradoxically but perhaps inevitably that Albanians 
are completely taken up with proving their intrinsic kind. Agnates do not become, they are agnates in perpetuity, all the way back from the beginning, from the very root or aptly the "seed" of kinship (farefis). For Albanians, gjaku ujë nuk bëhet, "blood cannot be watered down", a fact that they often assert explicitly.

What these people are saying, quite explicitly, goes beyond the simple question of whether or not the physiological process of fathering children is known. Sexual intercourse is a necessary condition, but paternity is not merely an awareness of the connection between sexual intercourse and pregnancy, which cannot serve purely to affirm the social recognition of paternity. A woman gets pregnant because she conceives, and it is this ideological notion of conception that is far more important. Traditionally, the physiological contribution to the child was coded differently for men and women, and therefore their connection to the child was imagined as different. Women are fertile and maternity was meant to give birth and give nurture, whereas paternity has meant begetting, which was seen as the primary, essential and creative role, making man bring reason, order and regulation in the created life. Precisely for that reason, the cultural activism that exacerbates the family ideology of blood and honor can become necessary as additional agency for the political effectiveness of war rapes to take place as an instrument of ethnic cleansing and genocide.

In turn, cultural activism should allow us to account for the structural, historical and political conditions in which social behavior takes place. A more experiential understanding of ethnographic evidence [31], as in the case of sex selection at birth [1] or ways of expressing labor pain at childbirth [166], can make us aware that people are not necessarily bound by culture. The fact that women unwillingly speak of their atrocious experiences of rape and sexual violence, preferring to stay silent about them, or if they speak, to preserve anonymity, should at least make social scientists curious about those women who do not talk and about their refusal to give testimonies in front of TV cameras. There is no evidence of such an awareness on the part of any of the great promoters of women's rights who choose instead to explain their refusal through almost exclusively culturalist discussions that make essential the traditionalist-survivalist concepts of shame and honor.

Since Ernest Renan and his pioneering conceptualization of nationality, we know that history is full of meaningful silences, where the things that are deemed to oblivion or relegated to the not-said suggest what preoccupies a society better than what is said and is remembered [167]. After genocide, a resourceful art of "remembering to forget" must have moved Rwanda the way forward to a success story [168, 169]. In Southeast European and more generally Mediterranean societies, it is always the façade of honor which needs to be upheld to maintain social status and integrity, independent of anything that has actually happened, and this is best achieved through silence about potentially disruptive facts [170]. That is why a culturalist linking of rape with ideas of honor is always mistaken and as reports from the former Yugoslavia indicate, violations of honor and modesty are wholly inadequate concepts to express the suffering of women raped during war ([64]:674). This means that "the silence of war rape forms a black hole in the collective memory" that harks back to cultural contest rather than to actual experience or post-fact construction ([171]:48-49).

Surely, empathy and trust of various kinds are prerequisite in understanding and coming to terms with women's silence, especially in the context of a fundamental lack of trust even in a mechanism of transitional justice that appears to avoid the traps of 
courtroom justice or a feminist approach to justice. Subjectivity in suffering may be socially conditioned but the individual ways of expressing subjectivity after trauma are not culture-determined, but context-dependent, mostly escapist and sometimes subversive, as in the case of Albanian women, victims of war rape in Kosovo. Women's political subjectivity, or women's voice, can also be expressed through silence, which can be seen as one of the many strategic choices and can have different meanings within specific institutional and cultural contexts [172]. While silence is seen as a reflection of the patriarchal order, and as the embodiment of political and social oppression, the continual recreation and manipulation of the various links between women's voice and silence are culturally constructed in close relation to power and gender, but people do not necessarily follow cultural dictates.

In a way alike Foucault arguing that "points of resistance are present everywhere in the power network" ([173]:96), Lévi-Strauss might put that voice and silence convey the same coded information in a looped message transmitted in different contexts, while "the role of structural analysis is to look beyond the apparent disorder of phenomena and to restore the underlying order" ([18]:190). Arguably, as a specific social behavior related to honor values and practices, like migration and dislocation, silence could be another indirect indication of women's agency to resist the traditionalist-survivalist frameworks of patriarchal ideology, thus emerging as only but one important strategy of avoiding the social consequences of cultural activism. In the aftermath of war in Kosovo, women's silence should also be seen as an affirmative strategy of resistance, not a symbol of passivity and powerlessness ([174]:163), but another context among the manifestations of women's agency examined elsewhere as a strategic defense against ideas of cultural coherence aiming to maintain the existing order of power and gender [36].

Not only the media and many accounts often omitted paradoxically to mention that in Bosnia and in Kosovo people "are struggling to love children of hate", but at different times and for different reasons, Kosovo survivors of sexual violence have followed either a strategy of silence or one of speech. Lately they also resolved to ask for recognition and to lobby for reparations. After war, it was not reticence, or a sense of honor propriety and chastity, which stopped Albanian women from testifying, but their experience of betrayal by the institutions, by the society, and by their own families [67]. Facing what they perceived as social and institutional indifference, they had chosen silence. This convergence of individual and social silence might have been a sort of complicity of the powerless with imposed silences, or a "silent security dilemma" [175] constrained by social exclusion, traditions, and the dominance of exclusionary public discourses, where speaking may endanger the speaker and silence is the only choice.

While some women may be silent, the image of the shamed, silent woman victim in Bosnia or in Kosovo is patently inaccurate. Indeed, when they speak to denounce the crime they suffered, "they talk about these crimes with openness and anger, not shame" ([106]:79). The reluctance Albanian women to speak about their experiences can be seen as negating the various institutional spaces that in Kosovo persistently demand that Albanian women speak out. Seemingly, they might have perceived the techniques of the political economy of language as generalized and diffuse means of exercising power through judgment, categorization, surveillance, and documentation ([174]:164). They also rebelled against the control of male hierarchy to maintain rules of honor and propriety, which oppressed and suffocated both women and men. Some dissented because the style and organization of reporting of human rights violations often erased "the 
identity of victims of sexual violence with a stroke of the pen, so that they became known just as the wife, the daughter, or the cousin of some man". Others explicitly rebelled against the traditionalist opinion that women were "collateral damage, that the damage and violations didn't really affect the women, but the men" ([67]:627).

As a logical outcome, we may ultimately agree to consider that women's strategic choice of silence is directed above all against the gendered propaganda that fueled the cultural activism of honor ideology in preparation for the Yugoslav wars. Women's silence may be a strategic voice to make it ineffective and stop such cultural activism that first focused on the fertility of Albanian women in Kosovo and continued during the wars as a major mobilizing factor leading to the perpetration of human rights violations, sexual violence, crimes against humanity, and genocide in former Yugoslavia.

\section{Conclusion}

In attempting to analyze the empirical evidence of mass rapes, the aim of this article was to frame the argument in such a way as to focus on the problematization of different accounts and move away from the close association of a major and sensitive issue with the essentialization of culture, history, and society. After the "writing culture" debate [176] and the declaration of war against reification and essentialism, we have become even less able to address that dimension of human life on which anthropologists used to claim some expertise. Namely, the ordered system of acquired, cognitive and symbolic meanings in terms of which social behavior takes place, we still label "culture", and which is established by convention, reproduced by traditional transmission, and largely shared by a social group [146]. In our eagerness to deconstruct whatever entities were formerly considered to be "out there" and to highlight process and agency over structure and culture, as already pointed by scholars concerned with honor killings [177], we have contributed to making it intellectually and politically contentious to talk intelligently about differences that very tangibly affect people's lives.

Similarly, to accept the validity of rapes testimony of both victims and perpetrators about the lack of freedom experienced by many women or about the male dominance over female victims is to offer a blanket condemnation of culture as a given determinant of social behavior. Acknowledging the cultural dimensions of human acts and motives need not imply a reductionist understanding of culture. To account for the structural, historical and political conditions in which social behavior takes place is not to reduce all members of a community to social beings who "have a culture" and are "culturally determined" in their individual experiences, their subjectivity of suffering and their personal aspirations, nor that they are pre-programmed to react in the same manner always and everywhere.

Anthropologists using feminist approaches to analyze gendered dimensions of war violence, whether in former Yugoslavia [66, 71, 103, 104], or elsewhere, are deeply sensitive to the ways in which both historical context and cultural background may influence the political and war-strategic meaning of rapes. They explore how conceptions about accountability and expected gender roles in a particular time and place may lead social actors to commit atrocities that transgress the moral codes of their own society, while condemning their victims to silence [171]. We argued here for a critical approach to the hegemonic commitments by focusing on the political process of 
cultural activism and ideology that define the strategic effectiveness of mass rapes as an instrument of ethnic cleansing. The aim of this article was not to provide a new account of mass rapes in former Yugoslavia, but rather to examine how various interpretations and the political implications of these accounts have succeeded in obscuring, rather than explaining, the politics of mass rapes in ethnic conflict.

The mathematical validity to isolate cultural activism as a specific ideological and political instrumentality of mass rapes as a military strategy of ethnic cleansing in former Yugoslavia may appear unusual, and difficult to grasp, if one schematically employs traditional categories, as developed in some feminist accounts dealing with this question. In turn, an articulate analysis of the empirical evidence and local structures, linked to a neo-structural modelling of canonical formalization based on transformational morphodynamics, is likely to produce a more sophisticated and critical understanding of the purported role of cultural factors. Definitely, to understand how the sinisterly effective politics of mass rapes became possible, it is necessary to reveal how cultural activism and nationalist projects may mobilize a traditionalist-survivalist discourse that activates the cultural ideology of family honor and blood purity. Relying on a reified moral order and an assumed group ideology of people caught up in conflict, this deliberate activation construct both gender and war, indeed en-gendering the war itself. In this sense, there are not the actual cultural norms and social structures that involve a re-traditionalism of cultural and moral values. It is the deliberate discursive activation of cultural activism that fuels such a re-traditionalism, while the instrumental use of both identity politics and moral values promotes a new hidden agency that make it possible for mass rapes to become an effective weapon of ethnic cleansing. Eventually, the side effect of this situation seems to be a potential underestimation of the pressing problems before the massive occurrence of the phenomenon and the ineffectiveness of international arrangements to provide justice to survivors.

In methodological terms, we tried to engage with a comparative analysis and formalization of the empirical evidence on motivations and practices rather than with a search for positive literal proof. This approach might not be exhaustive, and certainly, a number of questions remain open. However, if these methodological reflections have managed to provoke at the very least a non-stereotyped discussion on the mathematical validity of the role of cultural ideology as a logical necessity of the politics of mass rapes in ethnic conflict, they will hopefully constitute a starting point for further debate and deeper enquiries that may yield alternative explanations. Ultimately, while the difficulty of simultaneously using distinct intersubjective approaches and taking into account distinct strands of explanatory interpretations is clearly realized, the attempt to articulate them in relation to one another may lead to a fascinating intellectual problem. The conceptual aspects of this approach may not only show how to deal with an extant problem of social justice but may also have important theoretical and methodological implications beyond those of the specific issue addressed in this article.

If we agree with the epistemological insight inspired from the structural study of myth, an ultimate innovative direction can be argued to establish a more sophisticated approach following structural procedures of transformational analysis and formalization. While it may not hitherto have been expressed so directly, this means that we may be correct in asserting that from an empirical situation of social change, including social 
conflict, identity construction and ethnic identification, transcribed in canonical way, we can in theory deduce the possibly hidden reality of an external boundary, borderland existence, or border-crossing movement. The social morphodynamics of this reality would reveal itself in the form of an ideologically or politically instrumental agency, just as the morphodynamic analysis of ethnic rapes is an illustrative example revealing the workings of family honor and blood ideology. The hidden reality so revealed will necessarily be organized around a specific category of social hierarchy associated with the value of one identity element, human agency and social action, but having inverse propositional characteristics to that element, course of action and agency. To put it the other way around, new social change and identity construction can be anticipated as a result of the mediating logical operation of a boundary condition within the same sociocultural or institutional frameworks, and we can be able to set off in their search and their appreciation.

Finally, if we are correct in these assumptions overall, a new anthropologically informed movement is born in social theory, which may be called neo-structural constructivism and which shall account for the structural dynamics of change and conflict while revealing the hidden aspect of ideological agencies and political projects. The conceptual aspects of this new approach suggest that it is important not to rely only on surface observations of data and ethnography. Rather, critical analysis of empirical evidence and intersections of ethnography with both experiential understanding and structural formalization can yield new insights in the space between idiographic and nomothetic understandings of culture, politics, and ideology.

Acknowledgments Interest on this topic started almost twenty years ago when war mass rapes were still waged in Kosovo. Different aspects were presented in several research seminars and conferences. Aspects of the critical review of literature on mass rapes over the 1990s were presented in the Stoetzel Seminars on Social Anthropology and Psychology in Paris Sorbonne (2000). Aspects of the boundary condition in social and anthropological theory were presented in the Centre for Border Studies at the University of Glamorgan/South Wales U.K. (2003), in the Annual Meeting of the American Anthropological Association in Philadelphia PA (2009), and in the Visiting Scholars Seminar at Harvard University (2017). Several aspects of the morphodynamics approach to mass rapes were presented in the Medical Anthropology Seminar at the University College London (2004), in the Annual Conference of the Anthropological Association of Ireland at the University of Limerick (2004), in the Conference on War and Sexual Violence at the Graduate Center of the City University of New York (2016), and in the Interdisciplinary Forum on Rape Cultures and Survivors in Santa Barbara CA (2018). I am thankful to Katherine Verdery, Roland Littlewood, Sarah Danielson, Tuba Inal, Merril Smith, Marie-Louise Pellegrin, and to the organizers and all other participants for their comments and discussions. A special thanks also to Nita Luci, Ruth Seifert and Zarana Papic for their help with many useful materials on mass rapes at the beginning of this work and to the anonymous reviewers for their constructive comments at the final stage.

Publisher's Note Springer Nature remains neutral with regard to jurisdictional claims in published maps and institutional affiliations.

\section{References}

1. Doja, A. (2010). Fertility Trends, Marriage Patterns, and Savant Typologies in Albanian Context. Journal of Family History, 35(4), 346-367. https://doi.org/10.1177/0363199010381045.

2. Inglehart, R., \& Welzel, C. (2005). Modernization, cultural change, and democracy: The human development sequence. Cambridge: Cambridge University Press. 
3. Doja, A. (2005). The Advent of Heroic Anthropology in the History of Ideas. Journal of the History of Ideas, 66(4), 633-650. https://doi.org/10.1353/jhi.2005.0054.

4. Doja, A. (2006). The predicament of heroic anthropology. Anthropology Today, 22(3), 18-22. https://doi.org/10.1111/j.1467-8322.2006.00439.x.

5. Doja, A. (2006). The shoulders of our giants: Claude Lévi-Strauss and his legacy in current anthropology. Social Science Information, 45(1), 79-107. https://doi.org/10.1177/0539018406061104.

6. Doja, A. (2008). Claude Lévi-Strauss at his Centennial: toward a future anthropology. Theory, Culture \& Society, 25(7-8), 321-340. https://doi.org/10.1177/0263276408097810.

7. Doja, A. (2010). Claude Lévi-Strauss (1908-2009): The apotheosis of heroic anthropology. Anthropology Today, 26(5), 18-23. https://doi.org/10.1111/j.1467-8322.2010.00758.x.

8. Doja, A. (2006). The Kind of Writing: anthropology and the rhetorical reproduction of post-modernism. Critique of Anthropology, 26(2), 157-180. https://doi.org/10.1177/0308275X06064993.

9. Doja, A. (2007). Creative misreading and bricolage writing: A structural appraisal of a poststructuralist debate. Portuguese Review of the History of the Book, 11(22), 89-104.

10. Wiseman, B. (Ed.). (2009). The Cambridge companion to Lévi-Strauss. Cambridge: Cambridge University Press.

11. Doja, A. (2008). From Neolithic Naturalness to Tristes Tropiques: the emergence of Lévi-Strauss's new humanism. Theory, Culture \& Society, 25(1), 77-100. https://doi.org/10.1177/0263276407090015.

12. Doja, A. (2009). Morphodynamics and Agency: From Post-Structuralism to Neo-Structuralism. Paper presented to the Invited Presidential Session Lévi-Strauss, Europe and the Ends of Anthropology, American Anthropological Association 108th Annual Meeting, Philadelphia, PA, December 2-6, 2009.

13. Doja, A. (2018). Social Morphodynamics: Mapping Identity Transformations, Cultural Encounters, and the Evolution of Core Values. Social Epistemology Review and Reply Collective, 7(1), 14-25.

14. Lévi-Strauss, C. (1955). La structure des mythes. In Anthropologie structurale (pp. 227-255). Paris: Plon.

15. Lévi-Strauss, C. (1964). Le Cru et le Cuit (Vol. 1, Mythologiques). Paris: Plon.

16. Lévi-Strauss, C. (1966). Du miel aux cendres (Vol. 2, Mythologiques). Paris: Plon.

17. Lévi-Strauss, C. (1968). L'origine des manières de table (Vol. 3, Mythologiques). Paris: Plon.

18. Lévi-Strauss, C. (1971). L'homme nu (Vol. 4, Mythologiques). Paris: Plon.

19. Lévi-Strauss, C. (1985). La potière jalouse. Paris: Plon.

20. Lévi-Strauss, C. (1991). Histoire de lynx. Paris: Plon.

21. Thom, R. (1972). Stabilité structurelle et morphogénèse: Essai d'une théorie générale des modèles. Paris: Interéditions.

22. Thom, R. (1981). Modèles mathématiques de la morphogenèse. Paris: Bourgois.

23. Desveaux, E. (2001). Quadratura Americana: Essai d'anthropologie lévi-straussienne. Genève: Georg Editeur.

24. Maranda, P. (Ed.). (2001). The double twist: From ethnography to morphodynamics. Toronto: University of Toronto Press.

25. Mosko, M. (1991). The canonic formula of myth and nonmyth. American Ethnologist, 18(1), $126-151$.

26. Petitot, J. (1988). Approche morphodynamique de la formule canonique du mythe. L'Homme: Revue Française d'Anthropologie, 28(106-107), 24-50.

27. Scubla, L. (1998). Lire Lévi-Strauss: Le déploiement d'une intuition. Paris: Odile Jacob.

28. Asch, M. (2005). Lévi-Strauss and the political: The elementary structures of kinship and the resolution of relations between indigenous peoples and settler states. Journal of the Royal Anthropological Institute, 11(3), 425-444. https://doi.org/10.1111/j.1467-9655.2005.00244.x.

29. Constable, N. (2009). The commodification of intimacy: Marriage, sex, and reproductive labor. Annual Review of Anthropology, 38(1), 49-64. https://doi.org/10.1146/annurev.anthro.37.081407.085133.

30. Marchart, O. (2008). Ungesellschaftliche Gesellschaftlichkeit: Exklusion und Antagonismus bei LéviStrauss, unter Berücksichtigung von Lacan, Laclau und Luhmann. Soziale Systeme: Zeitschrift für Soziologische Theorie, 14(2), 370-396.

31. Doja, A. (2013). Invitation au terrain: Mémoire personnel de la construction du projet socioanthropologique. Bruxelles: Peter Lang.

32. Doja, A. (1999). Amitié, alliance, parenté: idéologie et pratique dans la société traditionnelle. In G. Ravis-Giordani (Ed.), Amitiés: Histoire et Anthropologie (pp. 217-255). Aix-en-Provence: Presses de l'Université de Provence.

33. Doja, A. (1999). Morphologie traditionnelle de la société albanaise. Social Anthropology: Journal of the European Association of Social Anthropologists, 7(1), 37-55. https://doi.org/10.1111/j.1469-8676.1999. tb00177.x. 
34. Doja, A. (2000). Naître et grandir chez les Albanais: la construction culturelle de la personne. Paris/ Montreal: L'Harmattan.

35. Doja, A. (2014). Socializing Enchantment: a socio-anthropological approach to infant-directed singing, music education and cultural socialization. International Review of the Aesthetics and Sociology of Music, 45(1), 115-147 http://www.jstor.org/stable/23758170.

36. Doja, A. (2008). Instrumental borders of gender and religious conversions in the Balkans. Religion, State \& Society, 36(1), 55-63. https://doi.org/10.1080/09637490701809738.

37. Doja, A. (2000). Histoire et dialectique des idéologies et significations religieuses. The European Legacy: Towards New Paradigms, 5(5), 663-685. https://doi.org/10.1080/713665519.

38. Doja, A. (2000). The Politics of Religion in the Reconstruction of Identities. Critique of Anthropology, 20(4), 421-438. https://doi.org/10.1177/0308275X0002000404.

39. Doja, A. (2006). A Political History of Bektashism from Ottoman Anatolia to Contemporary Turkey. Journal of Church and State, 48(2), 423-450. https://doi.org/10.1093/jcs/48.2.423.

40. Doja, A. (2006). A Political History of Bektashism in Albania. Totalitarian Movements and Political Religions, 7(1), 83-107. https://doi.org/10.1080/14690760500477919.

41. Doja, A. (2006). Spiritual Surrender: From Companionship to Hierarchy in the History of Bektashism. Numen: International Review for the History of Religions, 53(4), 448-510. https://doi.org/10.1163 /156852706778941996.

42. Doja, A. (2011). Honneur, Foi et Croyance: approche linguistique anthropologique des valeurs morales et religieuses. Anthropos: International Review of Anthropology and Linguistics, 106(1), 161-172 http://www.jstor.org/stable/23031808.

43. Doja, A. (2013). The politics of religious dualism: Naim Frasheri and his elective affinity to religion in the course of 19th-century Albanian activism. Social Compass: International Review of Sociology of Religion, 60(1), 115-133. https://doi.org/10.1177/0037768612471770.

44. Abazi, E., \& Doja, A. (2013). Further Considerations on the Politics of Religious Discourse: Naim Frasheri and his Pantheism in the Course of Nineteenth-Century Albanian Nationalism. Middle Eastern Studies, 49(6), 859-879. https://doi.org/10.1080/00263206.2013.836495.

45. Abazi, E., \& Doja, A. (2016). International representations of Balkan wars: a socio-anthropological approach in international relations perspective. Cambridge Review of International Affairs, 29(2), 581610. https://doi.org/10.1080/09557571.2015.1118998.

46. Abazi, E., \& Doja, A. (2017). The past in the present: time and narrative of Balkan wars in media industry and international politics. Third World Quarterly, 38(4), 1012-1042. https://doi.org/10.1080 /01436597.2016.1191345.

47. Abazi, E., \& Doja, A. (2018). Time and narrative: Temporality, memory, and instant history of Balkan wars. Time \& Society, 27(2), 239-272. https://doi.org/10.1177/0961463x16678249.

48. Doja, A. (2016). Come costruire l'identità nel Regione Adriatico-Ionica: Prospettive culturali, regionali ed europei tra le idee civiche e le motivazioni stato-nazionale. In Innovazione e Integrazione nelle Politiche di Sviluppo Territoriale per la Regione Adriatico-Ionica: Proposte di Riflessione da una Prospettiva Locale e Regionale (pp. 216-220). Bologna: Adrigov.

49. Green, J. (2004). Uncovering collective rape: A comparative study of political sexual violence. International Journal of Sociology, 34(1), 97-116. https://doi.org/10.1080/00207659.2004.11043123.

50. Wood, E. (2006). Variation in sexual violence during war. Politics and Society, 34(3), 307-342. https://doi.org/10.1177/0032329206290426.

51. Cohen, D.-K. (2016). Rape during civil war. Ithaca: Cornell University Press.

52. Loken, M. (2017). Rethinking rape: The role of women in wartime violence. Security Studies, 26(1), 60-92. https://doi.org/10.1080/09636412.2017.1243915.

53. DeBrouwer, A.-M. (2005). Supranational criminal prosecution of sexual violence: The ICC and the practice of the ICTY and the ICTR. Antwerpen: Intersentia.

54. Stiglmayer, A. (Ed.). (1994). Mass rape: The war against women in Bosnia-Herzegovina. Lincoln: University of Nebraska Press.

55. Allen, B. (1996). Rape warfare: The hidden genocide in Bosnia-Herzegovina and Croatia. Minneapolis: University of Minnesota Press.

56. Card, C. (1996). Rape as a weapon of war. Hypatia: A Journal of Feminist Philosophy, 11(4), 5-18. https://doi.org/10.1111/j.1527-2001.1996.tb01031.x.

57. Kohn, E. (1994). Rape as a weapon of war: Women's human rights during the dissolution of Yugoslavia. Golden Gate University Law Review, 24(1), 199-221.

58. Tompkins, T. (1995). Prosecuting rape as a war crime: Speaking the unspeakable. Notre Dame Law Review, 70(4), 845-890. 
59. Copelon, R. (1994). Surfacing gender: Reconceptualizing crimes against women in time of war. In A. Stiglmayer (Ed.), Mass rape: The war against women in Bosnia-Herzegovina (pp. 197-218). Lincoln: University of Nebraska Press.

60. MacKinnon, C. (1994). Turning rape into pornography: Postmodern genocide. In A. Stiglmayer (Ed.), Mass rape: The war against women in Bosnia-Herzegovina (pp. 73-81). Lincoln: University of Nebraska Press.

61. Milillo, D. (2006). Rape as a tactic of war: Social and psychological perspectives. Affilia, 21(2), 196205. https://doi.org/10.1177/0886109905285822.

62. Seifert, R. (1994). War and rape: A preliminary analysis. In A. Stiglmayer (Ed.), Mass rape: The war against women in Bosnia-Herzeovina (pp. 54-72). Lincoln: University of Nebraska Press.

63. Sharlach, L. (2000). Rape as genocide: Bangladesh, the former Yugoslavia, and Rwanda. New Political Science, 22(1), 89-102.

64. Niarchos, C. (1995). Women, war, and rape: Challenges facing the International Tribunal for the Former Yugoslavia. Human Rights Quarterly, 17(4), 649-690. https://doi.org/10.1353/hrq.1995.0041.

65. Seifert, R. (2002). The female body as a symbol and a sign: Gender-specific violence and the cultural construction of war. In I. Taipale (Ed.), War or health? A reader. London: Zed Books.

66. Hayden, R. (2000). Rape and rape avoidance in ethno-national conflicts: Sexual violence in liminalized states. American Anthropologist, 102(1), 27-41.

67. DiLellio, A. (2016). Seeking justice for wartime sexual violence in Kosovo: Voices and silence of women. East European Politics \& Societies and Cultures, 30(3), 621-643. https://doi.org/10.1177 /0888325416630959.

68. Meron, T. (1993). Rape as a crime under international humanitarian law. American Journal of International Law, 87(3), 424-428. https://doi.org/10.2307/2203650.

69. Ginn, C. (2013). Ensuring the effective prosecution of sexually violent crimes in the Bosnian war crimes chamber: Applying lessons from the ICTY. Emory International Law Review, 27(1), 566-601.

70. Robinson, D. (1998). Trials, tribulations, and triumphs: Major developments in 1997 at the international criminal Tribunal for the Former Yugoslavia. Canadian Yearbook of International Law, 35, 179-213. https://doi.org/10.1017/S0069005800006627.

71. Olujic, M. (1998). Embodiment of terror: Gendered violence in peacetime and wartime in Croatia and Bosnia-Herzegovina. Medical Anthropology Quarterly, 12(1), 31-50.

72. Morokvasic, M. (1998). The logics of exclusion: Nationalism, sexism and the Yugoslav war. In N. Charles \& H. Hintjens (Eds.), Gender, ethnicity and political ideologies (pp. 65-90). London: Routledge.

73. Doja, A. (2001). Atrocités des conflits ethniques: paradoxes venus d'ailleurs ou sensations dans le cénacle savant. Social Anthropology: Journal of the European Association of Social Anthropologists, 9(2), 223-226. https://doi.org/10.1111/j.1469-8676.2001.tb00148.x.

74. Nahoum-Grappe, V. (1996). L'usage politique de la cruauté: l'épuration ethnique, ex-Yougoslavie, 19911995. In F. Héritier (Ed.), De la violence (pp. 275-323). Paris: Odile Jacob.

75. Charlesworth, H., \& Chinkin, C. (2000). The boundaries of international law: A feminist analysis. Manchester: Manchester University Press.

76. Engle, K. (2005). Feminism and its (dis)contents: Criminalizing wartime rape in Bosnia and Herzegovina. American Journal of International Law, 99(4), 778-816. https://doi.org/10.2307 13396669.

77. Campbell, K. (2007). The gender of transitional justice: Law, sexual violence and the international criminal Tribunal for the Former Yugoslavia. International Journal of Transitional Justice, 1(3), 411432. https://doi.org/10.1093/ijtj/ijm033.

78. Halley, J. (2009). Rape at Rome: Feminist interventions in the criminalization of sex-related violence in positive international criminal law. Michigan Journal of International Law, 30(1), 1-123.

79. Farnsworth, N. (Ed.). (2011). 1325 Facts \& Fables: A collection of stories about the implementation of UNSCR 1325 on women, peace, and security in Kosovo. Prishtina: KWN.

80. Subotic, G., \& Zaharijevic, A. (2017). Women between war Scylla and nationalist Charybdis: Legal interpretations of sexual violence in countries of former Yugoslavia. In J. Lahai \& K. Moyo (Eds.), Gender in human rights and transitional justice. New York: Palgrave-Macmillan.

81. Dembour, M.-B., \& Haslam, E. (2004). Silencing hearings? Victim-witnesses at war crimes trials. European Journal of International Law, 15(1), 151-177. https://doi.org/10.1093/ejil/15.1.151.

82. Kelsall, M., \& Stepakoff, S. (2007). When we wanted to talk about rape: Silencing sexual violence at the special court for Sierra Leone. International Journal of Transitional Justice, 1(3), 355-374. https://doi.org/10.1093/ijtj/ijm034. 
83. Mertus, J. (2004). Shouting from the bottom of the well: The impact of international trials for wartime rape on women's agency. International Feminist Journal of Politics, 6(1), 110-128. https://doi. org/10.1080/1461674032000165950.

84. Ross, F. (2010). An acknowledged failure: Women, voice, violence and the south African truth and reconciliation commission. In R. Shaw \& L. Waldorf (Eds.), Localizing transitional justice: Interventions and priorities after mass violence (pp. 69-91). Stanford: Stanford University Press.

85. McGlynn, C., \& Munro, V. (Eds.). (2010). Rethinking rape law: International and comparative perspectives. London: Routledge.

86. Halley, J., Kotiswaran, P., Rebouche, R., \& Shamir, H. (2018). Governance feminism: An introduction. Minneapolis: University of Minnesota Press.

87. Halley, J. (2006). Split decisions: How and why to take a break from feminism. Princeton: Princeton University Press.

88. Cohn, C. (Ed.). (2013). Women and wars. Cambridge: Polity Press.

89. Sjoberg, L. (Ed.). (2010). Gender and international security: Feminist perspectives. London/New York: Routledge.

90. Diken, B., \& Laustsen, C. (2005). Becoming abject: Rape as a weapon of war. Body \& Society, 11(1), 111-128. https://doi.org/10.1177/1357034X05049853.

91. Ellis, L. (1989). Theories of rape: Inquiries into the causes of sexual aggression. New York: Hemisphere Publishing.

92. Sanday, P. R. (1981). The socio-cultural context of rape: A cross-cultural study. Journal of Social Issues, 37(4), 5-27. https://doi.org/10.1111/j.1540-4560.1981.tb01068.x.

93. Symons, D. (1979). The evolution of human sexuality. New York: Oxford University Press.

94. Thornhill, R., \& Palmer, C. T. (2000). A natural history of rape: biological bases of sexual coercion. Cambridge, Mass.: MIT press.

95. Jewkes, R., Penn-Kekana, L., \& Rose-Junius, H. (2005). If they rape me, I can't blame them: Reflections on gender in the social context of child rape in South Africa and Namibia. Social Science \& Medicine, 61(8), 1809-1820. https://doi.org/10.1016/j.socscimed.2005.03.022.

96. Rejali, D. (1996). After feminist analyses of Bosnian violence. Peace Review, 8(3), 365-371.

97. Brownmiller, S. (1975). Against our will: Men, women and rape. New York: Bantam Books.

98. Nordstrom, C. (1996). Rape: Politics and theory in war and peace. Australian Feminist Studies, 11(23), $147-162$.

99. Enloe, C. (1993). The morning after: Sexual politics at the end of the cold war. Berkeley: University of California Press.

100. Littlewood, R. (1997). Military rape. Anthropology Today, 13(2), 7-16.

101. Carpenter, C. (2010). Forgetting children born of war: Setting the human rights agenda in Bosnia and beyond. New York: Columbia University Press.

102. Weitsman, P. (2008). The politics of identity and sexual violence: A review of Bosnia and Rwanda. Human Rights Quarterly, 30(3), 561-578. https://doi.org/10.1353/hrq.0.0024.

103. Helms, E. (2013). Innocence and victimhood: Gender, nation, and women's activism in postwar BosniaHerzegovina. Madison: University of Wisconsin Press.

104. Hromadzic, A. (2007). Challenging the discourse of Bosnian war rapes. In J. Johnson \& J. Robinson (Eds.), Living gender after communism (pp. 169-184). Bloomington: Indiana University Press.

105. Buss, D. (2009). Rethinking rape as a weapon of war. Feminist Legal Studies, 17(2), 145-163. https://doi.org/10.1007/s10691-009-9118-5.

106. Buss, D. (2014). Knowing women: Translating patriarchy in international criminal law. Social \& Legal Studies, 23(1), 73-92. https://doi.org/10.1177/0964663913487398.

107. Zarkov, D. (2007). The Body of War: Media, Ethnicity and Gender in the Break-up of Yugoslavia. Durham, N.C.: Duke University press.

108. Bringa, T. (1995). Being Muslim the Bosnian way: identity and community in a central Bosnian village. Princeton, N.J.: Princeton University press.

109. Brownmiller, S. (1994). Making female bodies the battlefield. In A. Stiglmayer (Ed.), Mass rape: The war against women in Bosnia-Herzegovina (pp. 180-182). Lincoln: University of Nebraska Press.

110. Hansen, L. (2001). Gender, nation, rape: Bosnia and the construction of security. International Feminist Journal of Politics, 3(1), 55-75. https://doi.org/10.1080/14616740010019848.

111. Bracewell, W. (2000). Rape in Kosovo: Masculinity and Serbian nationalism. Nations and Nationalism, 6(4), 563-590. https://doi.org/10.1111/j.1354-5078.2000.00563.x.

112. Sells, M. (1996). The bridge betrayed: Religion and genocide in Bosnia. Berkeley: University of California Press.

113. Herzfeld, M. (2001). Anthropology: Theoretical practice in culture and society. Oxford: Blackwell. 
114. Lévi-Strauss, C. (1967). Les structures élémentaires de la parenté (2e ed.). Paris/Hague: Mouton.

115. Leach, E. (1955). Polyandry, inheritance and the definition of marriage. Man, 55(12.199), $182-186$. https://doi.org/10.2307/2795331.

116. Halpern, J., \& Kideckel, D. (1983). The anthropology of Eastern Europe. Annual Review of Anthropology, 12, 377-402. https://doi.org/10.1146/annurev.an.12.100183.002113.

117. Cvijic, J. (1918). La Péninsule balkanique: géographie humaine. Paris: Armand Colin.

118. Boose, L. (2002). National countermemories crossing the river Drina: Bosnian rape camps, Turkish impalement, and Serb cultural memory. Signs: Journal of Women in Culture and Society, 28(1), 71-96. https://doi.org/10.1086/340921.

119. Halilovich, H. (2013). Places of pain: Forced displacement, popular memory, and trans-local identities in Bosnian war-torn communities. New York: Berghahn.

120. Skjelsbæk, I. (2006). Victim and survivor: Narrated social identities of women who experienced rape during the war in Bosnia-Herzegovina. Feminism \& Psychology, 16(4), 373-403. https://doi. org/10.1177/0959353506068746.

121. Salzman, T. (1998). Rape camps as a means of ethnic cleansing: Religious, cultural, and ethical responses to rape victims in the former Yugoslavia. Human Rights Quarterly, 20(2), 348-378.

122. Fisher, S. (1996). Occupation of the womb: Forced impregnation as genocide. Duke Law Journal, 46(1), 91-133.

123. Woodward, S. (1995). Balkan tragedy: Chaos and dissolution after the cold war. Washington, D.C.: Brookings Institution.

124. Korac, M. (1998). Ethnic-nationalism, wars and the patterns of social, political and sexual violence against women: The case of post-Yugoslav countries. Identities: Global Studies in Culture and Power, 5(2), 153-181. https://doi.org/10.1080/1070289X.1998.9962614.

125. Doja, A. (2016). Raw madness and cooked evil: The unspeakable politics of mass rapes as an instrument of ethnic cleansing. Paper presented to the International Conference War and Sexual Violence, Graduate Center, City University of New York, 28-29 April 2016.

126. Doja, A. (2018). Rethinking the politics of mass rapes as a military strategy and instrument of ethnic cleansing. In T. Inal \& M. Smith (Eds.), Rape Cultures and Survivors: An international perspective (pp. 23-61). Santa Barbara: Preager.

127. Booth, K. (Ed.). (2001). The Kosovo tragedy: The human rights dimensions. London: Frank Cass.

128. Henry, N. (2011). War and rape: Law, memory, and justice. New York: Routledge.

129. MacKinnon, C. (2006). Are women human? and other international dialogues. Cambridge, Mass.: Belknap press.

130. Hazan, P. (2000). La justice face à la guerre: de Nuremberg à La Haye. Paris: Stock.

131. Kesic, V. (1994). A response to Catharine MacKinnon's article turning rape into pornography: Postmodern genocide. Hastings Women's Law Journal, 5(2), 267-280.

132. Korac, M. (1994). Representation of mass rape in ethnic-conflicts in what was Yugoslavia. Sociologija: Časopis za sociologiju, socijalnu psihologiju i socijalnu antropologiju, 36(4), 495-514.

133. Tajfel, H. (1981). Human groups and social categories: Studies in social psychology. Cambridge: Cambridge University Press.

134. Fearon, J., \& Laitin, D. (2000). Violence and the social construction of ethnic identity. International Organization, 54(4), 845-877. https://doi.org/10.1162/002081800551398.

135. Jones, A. (1994). Gender and ethnic conflict in ex-Yugoslavia. Ethnic and Racial Studies, 17(1), 115-134.

136. Mertus, J. (1999). Women in Kosovo: Contested terrains: The role of national identity in shaping and challenging gender identity. In S. P. Ramet (Ed.), Gender politics in the Western Balkans: Women and society in Yugoslavia and the Yugoslav successor states (pp. 171-186). University Park: Pennsylvania State University Press.

137. Fein, H. (1999). Genocide and gender: The uses of women and group destiny. Journal of Genocide Research, 1(1), 43-63.

138. Leaning, J., Bartels, S., \& Mowafi, H. (2009). Sexual violence during war and forced migration. In S. F. Martin \& J. Tirman (Eds.), Women, migration, and conflict: Breaking a deadly cycle (pp. 173-199). Dordrecht/New York: Springer.

139. Becirevic, E. (2014). Genocide on the Drina River. New Haven: Yale University Press.

140. Cohen, P. (1996). The complicity of Serbian intellectuals in genocide in the 1990s. In T. Cushman \& S. Mestrovic (Eds.), This time we knew: Western responses to genocide in Bosnia (pp. 39-65). New York: New York University Press.

141. Cushman, T. (2004). Anthropology and genocide in the Balkans: An analysis of conceptual practices of power. Anthropological Theory, 4(1), 5-28. https://doi.org/10.1177/1463499604040845.

142. Lentin, R. (Ed.). (1997). Gender and catastrophe. London: Zed Books. 
143. Bowman, G. (1994). Xenophobia, fantasy and the nation: The logic of ethnic violence in former Yugoslavia. In V. Goddard, J. Llobera, \& C. Shore (Eds.), Anthropology of Europe: Identity and boundaries in conflict (pp. 143-171). London: Berg Publishers.

144. Doja, A. (2001). Démocratie et stabilité dans le Sud-Est européen. Les Temps Modernes, 56(4/615-616), 147-166. https://doi.org/10.3917/ltm.615.0147.

145. Foucault, M. (1969). L'Archéologie du savoir. Paris: Gallimard.

146. Geertz, C. (1973). The interpretation of cultures: Selected essays. New York: Basic Books.

147. Benedict, R. (1934). Patterns of culture. Boston: Houghton Mifflin.

148. Peristiany, J. (Ed.). (1966). Honour and shame: The values of Mediterranean society. London: Weidenfeld \& Nicholson.

149. Campbell, J. (1964). Honour, family, and patronage: A study of institutions and moral values in a Greek mountain community. Oxford: Clarendon.

150. Denich, B. (1974). Sex and power in the Balkans. In M. Rosaldo, \& L. Lamphere (Eds.), Woman, culture, and society (pp. 243-262). Stanford, Calif.: Stanford University Press.

151. Backer, B. (1979). Behind stone walls: Changing household organization among the Albanians of Kosova. Masters thesis, Institute of Social Anthropology, University of Oslo. Reprint, Peja: Dukagjini books, 2003.

152. Mookherjee, N. (2006). Remembering to forget: Public secrecy and memory of sexual violence in the Bangladesh war of 1971. Journal of the Royal Anthropological Institute, 12(2), 433-450. https://doi. org/10.1111/j.1467-9655.2006.00299.x.

153. Abramowitz, S., \& Moran, M. (2012). International human rights, gender-based violence, and discourses of abuse in post-conflict Liberia: A problem of culture. African Studies Review, 55(2), 119-146. https://doi.org/10.1353/arw.2012.0037.

154. Burnet, J. (2012). Situating sexual violence in Rwanda (1990-2001): Sexual agency, sexual consent, and the political economy of war. African American Review, 55(2), 97-118. https://doi.org/10.1353 /arw.2012.0034.

155. Sanford, V., Stefatos, K., \& Salvi, C. (Eds.). (2016). Gender Violence in Peace and War: States of Complicity. New Brunswick, N.J: Rutgers University Press.

156. Theidon, K. (2013). Intimate enemies: Violence and reconciliation in Peru. Philadelphia: University of Pennsylvania Press.

157. Lončar, M., Medved, V., Jovanović, N., \& Hotujac, L. (2006). Psychological consequences of rape on women in 1991-1995 war in Croatia and Bosnia and Herzegovina. Croatian Medical Journal, 47(1), 67-75.

158. McGinn, T. (2000). Reproductive health of war-affected populations: What do we know? International Family Planning Perspectives, 26(4), 174-180. https://doi.org/10.2307/2648255.

159. Harris, R. (1993). The child of the barbarian: Rape, race and nationalism in France during the first world war. Past \& Present, 141(1), 170-206. https://doi.org/10.1093/past/141.1.170.

160. Kaser, K. (2008). Patriarchy after patriarchy: Gender relations in Turkey and in the Balkans, 15002000. Münster: LIT-Verlag.

161. Doja, A. (1995). Le sexe de la naissance: masculin-féminin dans la société traditionnelle albanaise. Ethnologie Française, 25(4), 650-667. http://www.jstor.org/stable/40989578.

162. Malinowski, B. (1962). Sex, culture, and myth. New York: Harcourt Brace.

163. Héritier, F. (1996). Masculin/féminin: la pensée de la différence. Paris: Odile Jacob.

164. Leach, E. (1966). Virgin birth. In S. Hugh-Jones, \& J. Laidlaw (Eds.), Culture and human nature (The Essential Edmund Leach, vol. 2, pp. 102-119). London: Yale University press, 2000.

165. Delaney, C. (1986). The meaning of paternity and the virgin birth debate. Man, 21(3), 494-513. https://doi.org/10.2307/2803098.

166. Doja, A. (2005). Social Thought \& Commentary: Rethinking the Couvade. Anthropological Quarterly, 78(4), 919-951. https://doi.org/10.1353/anq.2005.0053.

167. Renan, E. (1882). Qu'est-ce qu'une nation? Paris: Bordas.

168. Buckley-Zistel, S. (2006). Remembering to forget: chosen amnesia as a strategy for local coexistence in post-genocide Rwanda. Africa, 76(2), 131-150. https://doi.org/10.3366/afr.2006.76.2.131.

169. Meierhenrich, J. (2011). Topographies of remembering and forgetting: the transformation of Lieux de Mémoire in Rwanda. In S. Straus \& L. Waldorf (Eds.), Remaking Rwanda: State Building and Human Rights After Mass Violence (pp. 283-296). Madison: University of Wisconsin Press.

170. Giordano, C. (2001). Mediterranean honour reconsidered: Anthropological fiction or actual action strategy. Anthropological Journal on European Cultures, 10, 39-58.

171. Boeschoten, R. (2003). The trauma of war rape: A comparative view on the Bosnian conflict and the Greek civil war. History and Anthropology, 14(1), 41-54. 
172. Gal, S. (1991). Between speech and silence: The problematics of research on language and gender. In M. DiLeonardo (Ed.), Gender at the crossroads of knowledge: Feminist anthropology in the postmodern era (pp. 175-203). Berkeley: University of California Press.

173. Foucault, M. (1980). Power/knowledge: Selected interviews and other writings, 1972-1977. New York: Pantheon Books.

174. Luci, N. (2004). Das Schweigen der Frauen: Genderkonstruktionen und Genderdynamiken in Kosova vor und nach dem Krieg. In R. Seifert (Ed.), Gender Identität und kriegerischer Konflikt in den Nachkriegsgesellschaften des ehemaligen Jugoslawien (pp. 152-170). Münster: Lit-Verlag.

175. Hansen, L. (2000). The little Mermaid's silent security dilemma and the absence of gender in the Copenhagen school. Millennium: Journal of International Studies, 29(2), 285-306. https://doi. org/10.1177/03058298000290020501.

176. Clifford, J., \& Marcus, G. (Eds.). (1986). Writing culture: The poetics and politics of ethnography. Berkeley: University of California Press.

177. Kurkiala, M. (2003). Interpreting honour killings: The story of Fadime Sahindal (1975-2002) in the Swedish press. Anthropology Today, 19(1), 6-7. https://doi.org/10.1111/1467-8322.00157. 